\title{
Notch signaling in female cancers: a multifaceted node to overcome drug resistance
}

\author{
Maria V. Giuli ${ }^{1}$, Angelica Mancusi ${ }^{1}$, Eugenia Giuliani ${ }^{2}$, Isabella Screpanti ${ }^{1}$, Saula Checquolo ${ }^{3,4}$ \\ 'Laboratory of Molecular Pathology, Department of Molecular Medicine, Sapienza University, Rome 00161, Italy. \\ ${ }^{2}$ Scientific Direction, San Gallicano Dermatological Institute IRCCS, Rome 00144, Italy. \\ ${ }^{3}$ Department of Medico-Surgical Sciences and Biotechnology, Sapienza University, Latina 04100, Italy. \\ ${ }^{4}$ Center for Life Nano Science@Sapienza, Istituto Italiano di Tecnologia, Rome 00161, Italy.
}

Correspondence to: Dr. Saula Checquolo, Department of Medico-Surgical Sciences and Biotechnology, Sapienza University, Corso della Repubblica 79, Latina 04100, Italy. E-mail: saula.checquolo@uniroma1.it

How to cite this article: Giuli MV, Mancusi A, Giuliani E, Screpanti I, Checquolo S. Notch signaling in female cancers: a multifaceted node to overcome drug resistance. Cancer Drug Resist 2021;4:805-36. https://dx.doi.org/10.20517/cdr.2021.53

Received: 9 Jun 2021 First Decision: 9 Jul 2021 Revised: 29 Jul 2021 Accepted: 3 Aug 2021 First online: 5 Aug 2021

Academic Editor: Godefridus J. Peters Copy Editor: Xi-Jun Chen Production Editor: Xi-Jun Chen

\begin{abstract}
Drug resistance is one of the main challenges in cancer therapy, including in the treatment of female-specific malignancies, which account for more than $60 \%$ of cancer cases among women. Therefore, elucidating the underlying molecular mechanisms is an urgent need in gynecological cancers to foster novel therapeutic approaches. Notably, Notch signaling, including either receptors or ligands, has emerged as a promising candidate given its multifaceted role in almost all of the hallmarks of cancer. Concerning the connection between Notch pathway and drug resistance in the afore-mentioned tumor contexts, several studies focused on the Notchdependent regulation of the cancer stem cell (CSC) subpopulation or the induction of the epithelial-tomesenchymal transition (EMT), both features implicated in either intrinsic or acquired resistance. Indeed, the present review provides an up-to-date overview of the published results on Notch signaling and EMT- or CSCdriven drug resistance. Moreover, other drug resistance-related mechanisms are examined such as the involvement of the Notch pathway in drug efflux and tumor microenvironment. Collectively, there is a long way to go before every facet will be fully understood; nevertheless, some small pieces are falling neatly into place. Overall, the main aim of this review is to provide strong evidence in support of Notch signaling inhibition as an effective strategy to evade or reverse resistance in female-specific cancers.
\end{abstract}


Keywords: Notch signaling, drug resistance, female-specific cancers, cancer stem cells, epithelial-to-mesenchymal transition, drug efflux, tumor microenvironment

\section{INTRODUCTION}

Cancer is one of the principal causes of death worldwide among women in both high-income and low/middle-income countries ${ }^{[1]}$. Notably, female-specific cancers such as breast, cervix, uterus corpus endometrial, and ovarian cancers (OCs) account for about $60 \%$ of cancer cases and deaths among the female population worldwide ${ }^{[1]}$. All these numbers reflect the magnitude of female cancers incidence and highlight how the management of these malignancies is still challenging. This is mainly due to frequent tumor relapses promoted by the resistance to common chemotherapeutic agents or targeted therapies, especially for breast ${ }^{[2]}$ and ovarian ${ }^{[3]}$ cancers.

On the whole, drug resistance can be divided into two wide categories, intrinsic or acquired resistance, depending on the presence of pre-existing resistance-mediating factors or their development during the treatment, respectively ${ }^{[4]}$. Despite this binary categorization, the underlying molecular mechanisms are the same $^{[5]}$ and rely on several factors, such as genetic instability, heterogeneity, enhanced drug efflux, inactivation of the drugs, epithelial-to-mesenchymal transition (EMT), cancer stem cell (CSC) phenotype acquisition, and the involvement of the tumor microenvironment (TME) $)^{[6]}$.

Since it has been extensively demonstrated that drug resistance limits the effectiveness of cancer therapy, finding novel therapeutic targets to evade or reverse it becomes of paramount importance ${ }^{[7]}$.

An increasing number of studies has focused on the involvement of Notch signaling in the promotion of drug resistance in female cancers, hence evaluating the efficacy of targeting this pathway, as Notch signaling has demonstrated an important role in the development of normal female-specific tissues as well as in the carcinogenesis and tumor progression of several cancers, including breast, cervical, endometrial, and

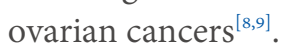

In the present review, we overview the Notch-dependent molecular mechanisms which drive drug resistance in gynecological cancers (as depicted in Figure 1). On the one hand, CSCs and EMT have been deeply studied and we summarize the literature where Notch targeting overcomes drug resistance by interfering in these processes. On the other hand, we evaluate the role of Notch signaling in the remaining mechanisms even if the connection between Notch targeting and evasion or reversion of resistance has not yet been thoroughly investigated, thus giving hints for further studies.

\section{OVERVIEW ON THE GYNECOLOGICAL CANCERS}

Breast cancer (BC) is the most frequently diagnosed tumor and the principal cause of cancer-related death among women worldwide with the highest BC incidence rates in North America, Australia, New Zealand, and Northern and Western Europe. In 2008, about 1.4 million new cases were estimated worldwide ${ }^{[10]}$ with nearly 459,000 related deaths ${ }^{[11]}$. It has been predicted that the worldwide incidence of this female cancer will reach approximately 3.2 million new cases per year by $2050^{[12]}$, suggesting that worldwide cancer incidence is on rise.

In high-income countries (HICs), (such as USA, Canada, Brazil, Israel, Australia, and some European countries), the 5 -year survival is $85 \%$, while in low/middle-income countries (LMICs) (such as South Africa 


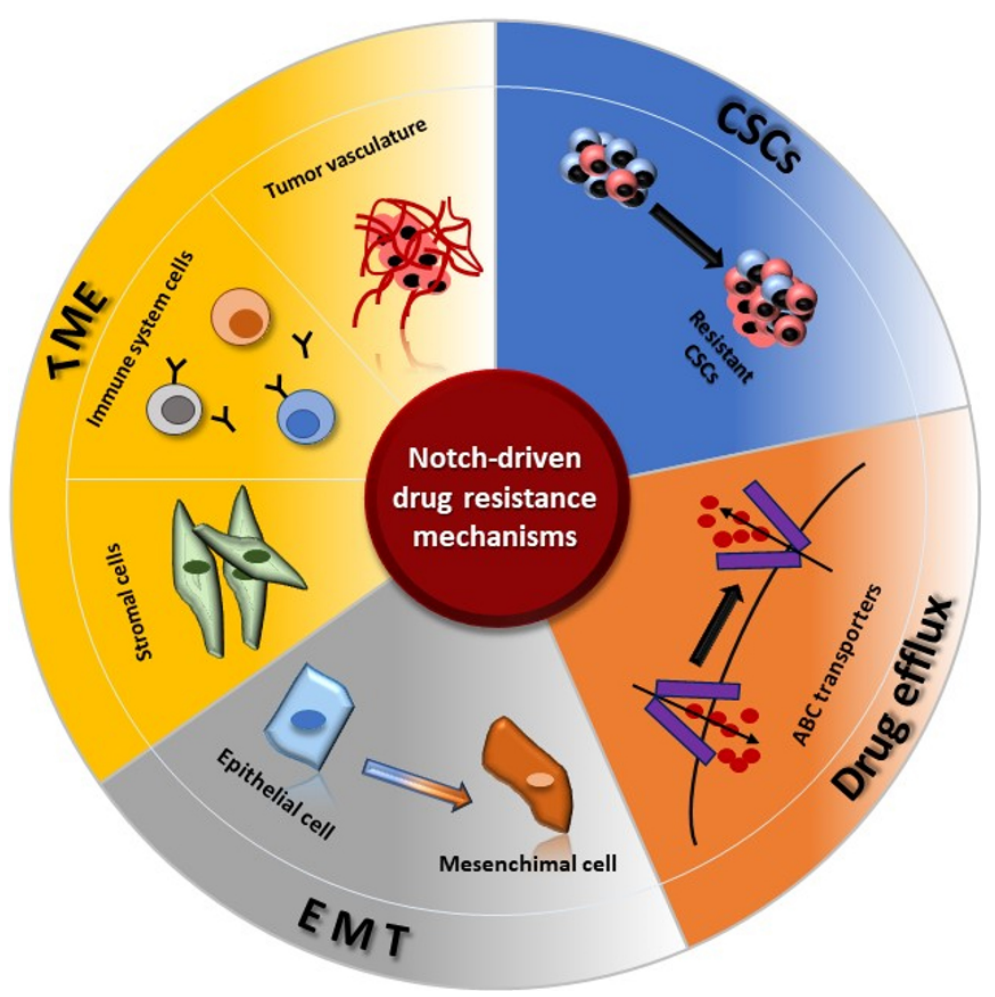

Figure 1. Notch-driven drug resistance mechanisms. The cartoon schematically depicts the involvement of Notch signaling in several drug resistance mechanisms [CSCs (cancer stem cells), drug efflux, EMT (epithelial-to-mesenchymal transition), and TME (tumor microenvironment)].

or India), the survival rate decreases to $60 \%^{[13]}$. Furthermore, it is estimated that the probability for a $30-$ year-old woman to develop BC over a 10-year period is about 10 times less than that for a 70 -year-old on $\mathrm{e}^{[14]}$. The prevalence of $\mathrm{BC}$ in the young population is increasing. In addition, in the younger population, the tumor is more aggressive ${ }^{[15]}$, showing a greater rate of recurrence than in older women ${ }^{[16]}$.

BCs are divided into five subtypes based on the expression of estrogen receptors (ER), progesterone receptors (PR), and HER2 oncogene. Overall, ER-positive tumors are usually smaller and lower grade than ER-negative ones ${ }^{[17]}$. The lack of expression of ER, PR, and HER2 characterizes the triple-negative breast cancer (TNBC) subtype, which accounts for approximately $15 \%$ of all BC cases $^{[18]}$, and it is the most aggressive subtype with the poorer outcomes ${ }^{[19]}$. TNBC incidence is generally higher in younger women, African and American women, and in patients with mutated BRCA1 gene ${ }^{[20]}$.

According to site, BCs are distinguished in non-invasive and invasive, also recognized as "metastatic" $\mathrm{BC}^{[21]}$.

In general, the $\mathrm{BC}$ risk factors include genetic history of the disease, BRCA1 or -2 mutations, endogenous estrogen, exposure to drinking, sedentariness, and the use of exogenous hormones ${ }^{[22]}$.

The primary option of $\mathrm{BC}$ treatment remains surgical intervention ${ }^{[23]}$. However, several broad classes of drugs are chosen according to tumor molecular characteristics: (1) systemic chemotherapy, which is generally recommended after definitive surgery; (2) hormonal treatment, such as anti-estrogen drugs; or (3) targeted therapies, which include the use of monoclonal antibodies. The most common drugs used for chemotherapy are docetaxel, paclitaxel, platinum agents (cisplatin and carboplatin), vinorelbine 
(Navelbine), capecitabine (Xeloda), liposomal doxorubicin (Doxil), and cyclophosphamide (Cytoxan) ${ }^{[24]}$. In addition, radiation therapy is used in combination with surgical intervention to optimize the treatment for each person's anatomy and reduce acute or long-term toxicity ${ }^{[25]}$. Current research efforts are oriented towards more personalized treatments to minimize side effects and improve patients' survival ${ }^{[26]}$.

$\mathrm{OC}$ is the second most common malignancy in women over the age of 40 , after $\mathrm{BC}^{[27]}$. Every year, about 200,000 new OC cases and 150,000 deaths are estimated worldwide ${ }^{[28]}$, thus representing the fifth leading cause of cancer-related death in women ${ }^{[29]}$.

The high death-to-incidence ratio is mainly due to the absence of specific symptoms and effective screening strategies; as a result, OC is diagnosed at an advanced stage of the disease, when metastases are distributed in the abdomen ${ }^{[30]}$. The incidence rates are lowest in Asia and Africa and highest in Northern and Eastern Europe, where there are also the highest mortality rates ${ }^{[31]}$. OC is rare in young women, especially under the age of 30. Conversely, the risk of incidence increases with age, with a drastic increase after the age of $50^{[31]}$.

OC is classified into three main subtypes: epithelial, germ cell, and stromal. Among the epithelial group, the most common histological type is the serous carcinoma, followed by endometrioid, clear cell, and mucinous histotypes $^{[32]}$.

It is reported that reproductive factors, hormonal factors, and lifestyle factors are associated with the risk of OC incidence $\mathrm{e}^{[3,33]}$.

OC-bearing patients are primarily undergoing a standard care consisting of combined cytoreductive surgery followed by platinum- and taxane-based chemotherapy ${ }^{[34]}$. The risk of relapse is around $50 \%$ within two years, mainly attributed to chemotherapy resistance ${ }^{[3]}$.

Cervical cancer (CC) is the fourth most frequently diagnosed cancer and represents a major global health challenge ${ }^{[35]}$. It is the fourth leading cause of cancer-related death ${ }^{[36]}$ with an overall survival estimated between $60 \%$ and $70 \%{ }^{[13]}$, showing a reduction by more than half over the past 30 years, thanks to the introduction of screening programs ${ }^{[37]}$. In LMICs, where mortality is 18 times higher than that observed in developed countries, it is the third most common cause of cancer death ${ }^{[31]}$.

The median age at diagnosis is 47 years in the United States, where almost 50\% of cases are diagnosed under age 35 years $^{[38]}$. In South Africa, more than 25\% of diagnoses are in women aged 40-49 years between 2004 and $2012^{[39]}$.

The main risk factor for this type of cancer is chronic infection with human papillomavirus (HPV) ${ }^{[40]}$. It has been estimated that approximately 291 million women have a cervical HPV infection at any given time ${ }^{[41]}$. However, about $85 \%$ of infections are spontaneously cleared from the body within a few years and only the persistent infections constitute a risk for cancer development ${ }^{[42]}$. To date, CC may be considered nearly completely preventable thanks to the availability of HPV vaccine and screening programs ${ }^{[1]}$, which also allows the diagnosis in early stages of tumors.

Cervical pre-cancerous lesions can be detected and treated early with cryo-therapy, loop electrosurgical excision procedure, or thermo-coagulation ${ }^{[43]}$, while the treatment of cancer lesions follows the criteria of the International Federation of Gynecology and Obstetrics clinical staging and derives from the disease extension at diagnosis. It might involve radical hysterectomy, chemo-radiation, or their combination ${ }^{[44]}$. 
Nevertheless, the use of the anti-vascular endothelial growth factor (VEGF) agent bevacizumab, which impinges on the vascularization phase of cancer cells required for tumor survival, has been shown to be capable of extending the overall survival beyond 12 months, and it is currently used in combination with carboplatin and paclitaxel in cancer treatment ${ }^{[45]}$.

Cancers of the uterine corpus, among which endometrial cancers (EC) are the most frequent, account for about $5 \%$ of worldwide cancer incidence among women. Incidence rates are generally higher in HICs, where early diagnosis and treatment is common due to early symptoms and the 5-year survival is around $80 \%{ }^{[46]}$. However, the cancer survival is lower in LMICs due to the few health services and treatments available $e^{[47]}$. The risk factors for uterine corpus cancer include excess body weight or diabetes, estrogen therapy, early menarche and late menopause, and polycystic ovary syndrome ${ }^{[48]}$. In contrast, pregnancy, oral contraceptive use, physical activity, and, unlike other cancers, smoking seem to be protective against risk ${ }^{[49]}$. The primary options for EC-bearing patients are surgery, radiotherapy with or without chemotherapy, or chemotherapy alone $e^{[50]}$.

As mentioned above, drug resistance is mainly responsible for causing treatment failure in almost all cancers, including the female-specific ones ${ }^{[51]}$.

To date, the major hope in the fight against those aggressive cancers is the discovery of novel "druggable" targets to evade or reverse resistance, and Notch signaling represents a promising candidate.

\section{NOTCH STRUCTURE AND SIGNALING AT A GLANCE}

The conserved Notch signaling pathway acts as a mediator of short-range cell-cell communication between neighboring cells and controls the cell proliferation, differentiation, and apoptosis ${ }^{[52]}$. As depicted in Figure 2, Notch receptors are single pass transmembrane proteins, initially synthesized as inactive precursors in the endoplasmic reticulum and subsequently cleaved by a furin-like protein convertase in the Golgi compartment ${ }^{[53]}$. The first cleavage ( $\left.\mathrm{S}_{1}\right)$ produces heterodimers expressed on the plasmatic membrane and containing a N-terminal ligand-accessible Notch extracellular domain (NECD) and a C-terminal Notch transmembrane region $(\mathrm{NTM})^{[54]}$.

The canonical Notch signaling is triggered by the association to specific ligands that mediate the interaction with adjacent cells $^{[55]}$. Mammals have four Notch paralogs (Notch1-4) with variable structural homology that display both redundant and unique functions ${ }^{[5]}$ and five canonical Notch ligands: Delta-like family (Dll1, Dll3, and Dll4) and Jagged family (Jagged1 and Jagged2) ${ }^{[57]}$. Following the binding to the Notch ligand, an S2 cleavage is triggered by the metalloprotease ADAM leading to the dissociation of the NECD and the production of a membrane-associated Notch extracellular truncated (NEXT) intermediat ${ }^{[58]}$ further cleaved (S3) by a $\gamma$-secretases enzyme complex (Presenilin 1 and 2, Nicastrin, APH1, and PEN2) ${ }^{[58,59]}$. The S3 cleavage results in the release of the active Notch intracellular domain (NICD) from the membrane, thus free to transfer to the nucleus where it interacts with the CBF1, suppressor of hairless, and Lag-1 (CSL) families of DNA binding proteins ${ }^{[60]}$. Subsequently, it forms an active complex with the co-activator mastermind-like family (MAML) leading to the upregulation of downstream target genes, such as hairy and enhancer of split (HES) $)^{[6]}$. In the absence of NICD, CSL interacts with a co-repressor complex, thus suppressing the transcription [Figure 2] ${ }^{[62]}$.

The Notch signaling pathway is known for its role in the regulation of cell self-renewal, differentiation, and proliferation during development ${ }^{[63]}$, as well as in the maintenance of homeostasis in adult tissue ${ }^{[64]}$. Not surprisingly, given its pivotal role in several processes, dysregulation of Notch signaling has been implicated 


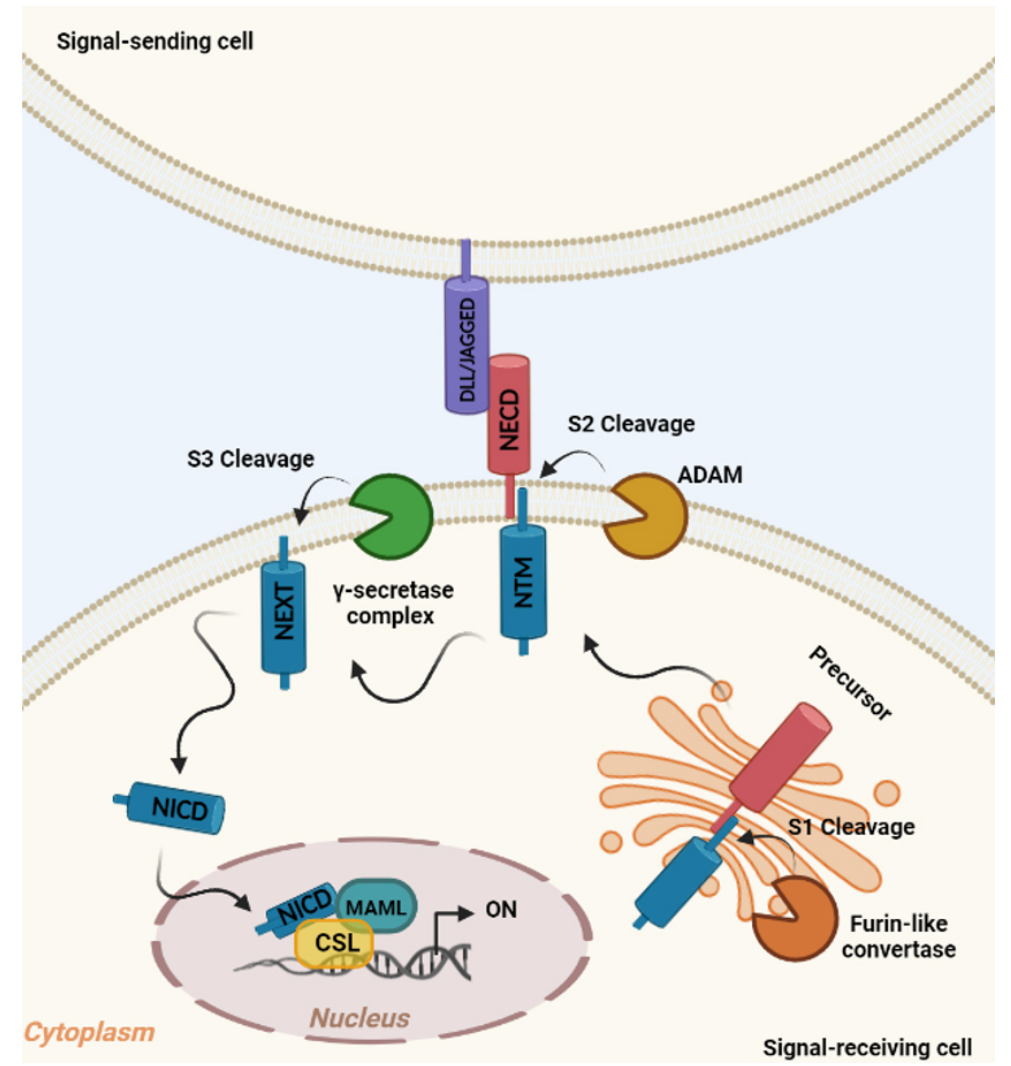

Figure 2. The canonical Notch signaling pathway. In the signal-receiving cell, the Notch receptor precursor is cleaved (S1) by Furin-like convertase in the Golgi compartment, thereby producing Notch extracellular domain (NECD) and Notch transmembrane region (NTM). Upon ligand binding (DLL/JAGGED) expressed on signal-sending cell, NTM is cleaved (S2) by ADAM, resulting in Notch extracellular truncated intermediate (NEXT) exposition to $\gamma$-secretase complex cleavage (S3). S3 cleavage allows the release of Notch intracellular domain (NICD), which translocates to the nucleus and interacts with transcriptional regulators (MAML and CSL) to activate the Notch target genes (ON).

in the development of cancer, as either an oncogene or a tumor suppressor ${ }^{[65]}$. Over the years, an oncosuppressive action of Notch receptors has been described in basal cell carcinoma of the skin, hepatocellular carcinoma, and B-cell lymphoblastic leukemia ${ }^{[6,67]}$. Conversely, Notch signaling acts as an oncogene in Tcell acute lymphoblastic leukemia where there are mutations affecting Notch1 in more than $50 \%$ of cases ${ }^{[68]}$. Notably, several studies documented the oncogenic role of Notch receptors in female-specific cancers ${ }^{[0]}$. In particular, dysregulation of Notch signaling is involved in the promotion of $\mathrm{BC}^{[69]}$, as well as in several hallmarks of OC such as proliferation, apoptosis, and metastasis ${ }^{[70]}$. Furthermore, the upregulation of the Notch pathway is a frequent event in EC, where it can increase the invasiveness of tumor cells ${ }^{[71]}$, and it is also associated with malignant behavior and poor prognosis in $\mathrm{CC}^{[72]}$.

Overall, the numerous reports regarding Notch signaling and gynecological cancers suggest the importance of considering it as a therapeutic target, especially in terms of drug resistance, as described in the following sections.

\section{NOTCH SIGNALING AND CSCS}

CSCs are a small subset of cancer cells with self-renewal potential, capable of giving rise to a heterogeneous tumor population ${ }^{[73,74]}$. CSCs are characterized by specific features, including the intense tumorigenic potential, the ability to grow as spheres under serum deprivation, and high levels of aldehyde 
dehydrogenase (ALDH1) activity ${ }^{[75]}$. Many studies have demonstrated that CSCs are more resistant to chemotherapy because of the higher expression of the anti-apoptotic proteins and multidrug resistance genes ${ }^{[76]}$. Indeed, during primary chemotherapeutic treatment, CSCs play an important role in tumor recurrence, preserving tumor growth and heterogeneity through various drug resistance mechanisms ${ }^{[77,78]}$ involving ALDH1 activity, DNA repair, and the activation of pro-proliferative signaling pathways ${ }^{[79]}$. Notably, the acquisition of stem cell characteristics is also linked to EMT ${ }^{[80]}$, further adding another molecular mechanism for CSC-dependent drug resistance. Indeed, the concept of CSCs displaying both EMT and self-renewal properties provides the rationale for cancer cells to migrate and populate metastatic sites. Part of this expansion is due to an influence imposed by CSCs on non-CSCs to recall an EMT program in the cells, thus shifting them toward drug-resistant $\mathrm{CSCs}^{[75]}$.

The role of Notch signaling in CSC functions has been well defined in several tumors ${ }^{[81]}$. Specifically, Notch pathway dysregulation is involved in the acquisition and maintenance of CSC-like properties by sustaining their self-renewal capacity ${ }^{[67]}$. As described in the following section, Notch pathway is also responsible for inducing EMT, which may result in the transformation of epithelial-like CSCs into cells with aggressive mesenchymal-like phenotypes ${ }^{[82]}$, thereby highlighting the potentiality of inhibiting Notch to hamper the interplay between CSCs and EMT phenomena.

Furthermore, a vast body of literature correlates Notch pathway to CSC-driven chemo-resistance ${ }^{[83,84]}$.

Exposure to chemotherapy, such as doxorubicin or docetaxel, as well as a hormone-based therapy, such as tamoxifen or fulvestrant, leads to an enrichment of ALDH+ BC stem cells (BCSCs) displaying resistance to these treatments ${ }^{[85]}$. Notch signaling is known to be pivotal for the maintenance of BCSCs and highly correlated with drug resistance ${ }^{[86,87]}$. Indeed, several studies documented that blocking Notch signaling reduces the stem-like population of BC cells by preventing mammosphere formation ${ }^{[8,89]}$. For instance, inhibition of Notch1 via the bioactive compound psoralidin or Notch1 silencing blocked the growth of ALDH1 + cells, thus resulting in a low mammosphere formation, increased apoptosis, and limited tumor growth in mice models ${ }^{[0]}$. Regarding chemotherapy, it has been demonstrated that TNBC cells treated with gemcitabine or paclitaxel displayed high levels of hypoxia-inducible factors (HIFs) activity, which is correlated with an increased BCSC population ${ }^{[1]]}$. Hypoxia exploits Notch signaling pathways to regulate the development of $\mathrm{CSCs}^{[92]}$. In this scenario, Yan et al. ${ }^{[93]}$ observed that Notch and Wnt signaling pathways may be activated by HIF-2 $\alpha$ overexpression, under hypoxia conditions, thus leading to the stem cell phenotype conversion in BCSCs and the overexpression of BCSC markers associated with paclitaxel resistance.

JAK/STAT pathway is crucial for BCSC self-renewal and cancer chemoresistance ${ }^{[94]}$. In addition, EZH2 binds to STAT3, which leads to the enhanced STAT3 activity via its increased tyrosine phosphorylation ${ }^{[95]}$. In keeping with these findings, more recently, it has been documented that chemotherapy activates the EZH2/STAT3 pathway in tumor cells, causing an increase in miR-378a-3p and miR-378d levels, in both cells and exosomes, which finally target the Notch pathway suppressor NUMB. This resulted in Notch overexpression and positive regulation of BCSC markers expression, thus confirming the involvement of Notch stem cell-associated pathways with paclitaxel and doxorubicin resistance of TNBCs ${ }^{[96]}$.

Moreover, Qiu et al. ${ }^{[97]}$ demonstrated that docetaxel treatment results in increased primary mammosphere formation and the specific block of Notch1 signaling enhanced chemotherapy efficacy by targeting BCSCs in vitro and in patient-derived xenograft (PDX) breast cancer models. 
It is worth mentioning that a molecular regulation mechanism of both Notch1 and Notch4 proteins has been shown, through which it is possible to control the BCSC drug resistance. In particular, Rustighiet al. ${ }^{[98]}$ showed that both receptors are able to escape from the Fbxw $7 \alpha$-dependent proteasomal degradation following interaction with the prolyl-isomerase Pin1, which is required for the Notch-dependent induction and maintenance of stem cell self-renewal in BSCSs. Furthermore, ablation of Pin 1 reduced the expression levels of Notch1/4, thus eliciting sensitivity to chemotherapeutic drugs and inhibiting tumor growth and metastatic spread in vivo ${ }^{[98]}$.

Concerning hormone-based therapy, Notch4 and its ligands have been demonstrated to play a crucial role, as Notch4 is found upregulated in BCSCs and conferred resistance to tamoxifen in part through the sustainment of BCSC amplification ${ }^{[99]}$. Additionally, Jagged1-Notch4 signaling activation in ALDH1+ cell populations has been observed as a determining factor in the acquisition of endocrine resistance in patientderived BCSCs. Consequently, the inhibition of Notch4 via $\gamma$-secretase inhibitors (GSIs) in vivo is able to abrogate BCSC activity, thus decreasing mammosphere formation of $\mathrm{BC}$ isolated cells in acquired tamoxifen resistant PDX tumors ${ }^{[100]}$. In keeping with these findings, more recently, it has been reported that FK506binding protein-like (FKBPL) reduces endocrine therapy BCSC-mediated resistance through the downregulation of Notch4 and its ligand Dll $4^{[101]}$.

Several studies documented that cancer cells gain resistance to targeted therapies by upregulating compensatory signaling pathways, including Notch signaling. As a result, Notch inhibition represents a promising approach to restore sensitivity to targeted treatments ${ }^{[102,103]}$.

For instance, it has been demonstrated that Notch3-specific inhibition increases TNBC sensitivity to the tyrosine kinase inhibitor (TKI) gefitinib, in TNBC-resistant cells, through regulating EGFR localization, thus rendering it readily targetable by the TKI gefitinib ${ }^{[102]}$. Moreover, a Notch binding sequence has been reported within the HER2 promoter, thus suggesting a mechanism for Notch/HER2 crosstalk ${ }^{[104,105]}$. HER2 expression is shown to be dependent upon Notch signaling in BCSCs: Farnie et al. ${ }^{[106]}$ obtained promising results by combining therapies targeting Notch and HER2, respectively, in ductal carcinoma in situ stem cells. Furthermore, blocking Notch activity by GSIs induces the downregulation of HER2 protein expression, as well as at the mRNA level, in HER2+ BC-derived mammospheres ${ }^{[107]}$. These studies documented the pivotal interaction between Notch1 and HER2 pathways, both of which are involved in the progression of breast cancer and regulation of BCSCs.

In keeping with these results, upon lapatinib treatment, which targets both EGFR and HER2 receptors, it has been observed that HER2+ breast cancer cells are enriched of high membrane-Jagged1-expressing BCSCs, thus resulting in a higher mammosphere forming efficiency causing lapatinib resistance ${ }^{[108]}$. In addition, the expression of Notch1, Jagged1, and their targets are increased after treatment with trastuzumab, which is a monoclonal antibody against HER2. The combined downregulation of Notch1 sensitizes BC cells to trastuzumab treatment ${ }^{[109]}$. More recently, Baker et al. ${ }^{[110]}$ showed that Notch 1 contributes to sustain the trastuzumab resistance of HER2+ BC cells, by influencing the survival and tumorinitiating potential of BCSCs through the repression of PTEN, which results in the activation of the proproliferative ERK1/2 signaling. These findings suggest that the high expression of Notch 1 may predict poorer survival in women with trastuzumab-resistant $\mathrm{BC}^{[110]}$. Moreover, PTEN downregulation increases the $\mathrm{PI} 3 \mathrm{~K} /$ Akt activity, frequently hyperactivated in $\mathrm{TNBC}^{[111]}$. The PI3K/Akt/mTOR signaling pathway is also imperative for the regulation of CSC self-renewal, and the cooperation of Notch and PI3K/Akt/mTOR signaling contributes to induce tumorigenesis and chemoresistance in solid tumors ${ }^{[112,113]}$. Similarly, highly expressed activated Akt is associated with chemoresistance in $\mathrm{BC}^{[114]}$ while $\mathrm{PI} 3 \mathrm{~K} / \mathrm{mTOR}$ inhibition sensitizes 
resistant cells to cytotoxic agents ${ }^{[115]}$. These findings suggest that inhibition of Notch sensitizes BC cells to chemotherapy by upregulating PTEN and consequently dampening PI3K/Akt/mTOR signaling.

It has been also demonstrated that Notch-dependent CSCs population sustains the resistance to PI3K or TORC1/2 inhibitors treatment in TNBCs. Indeed, Notch 1 activity is induced in TNBC cells by the use of a PI3K or TORC1/2, inhibitor and this is associated with the upregulation of mitochondrial metabolism and FGFR1 signaling. In particular, genetic blockade of Notch1 combined with PI3K or TORC1/2 inhibition abrogates the increase of BCSC markers, mammosphere formation, and in vivo tumor-initiating capacity, thus eradicating drug-resistant $\mathrm{BCSCs}{ }^{[116]}$.

Furthermore, Notch1-mediated crosstalk with the transcription factor NF- $\kappa \mathrm{B}$ signaling is evident in different tumors and both pathways are essential in maintaining the survival of $\operatorname{CSCs}^{[117]}$. An example of this interplay is explained in cervical and breast cancers where Notch1 forms a complex with the kinase IKK, which represents the core element of the NF- $\mathrm{KB}$ cascade, thus allowing its nuclear translocation ${ }^{[118,19]}$. However, the full interaction between these two pathways in the context of CSCs is not well understood. Recently, Hossain et al. ${ }^{[120]}$ demonstrated the involvement of Notch 1 in the NF- $\kappa B$ activation pathway and Akt phosphorylation via IKK kinase in TNBC cell resistance and CSCs formation. Pharmacological inhibition of Notch cleavage by GSI (PF-03084014) in combination with Akt inhibitor (MK-2206) or IKK inhibitor (Bay11-7082) blocks mammosphere formation and drug resistance, thus suggesting that combination strategies targeting at the same time Notch and PI3K/Akt or IKK/NF- $\mathrm{kB}$ may have potential therapeutic applications in targeting CSCs in TNBC context ${ }^{[120]}$.

The above-mentioned preclinical data clearly demonstrate that Notch signaling is crucial for BC drug resistance and provide evidence of the ability of Notch inhibitors to sensitize cells, including BCSCs, to treatments. Concerning clinical data, interesting results were obtained mainly in TNBCs. Two recent phase I clinical trials have deployed the use of GSIs in combination with chemotherapy for the treatment of patients with advanced BC, including TNBC subtype ${ }^{[121]}$. A combined effect of Notch GSI inhibitors (PF03084014) and docetaxel was recently observed in a phase 1 b study (NCT01876251), thereby showing clinical benefit in 25 patients with advanced TNBC ${ }^{[122]}$. Furthermore, this combination decreased ALDH1+ subpopulations and abrogated BCSCs by targeting the Notch signaling pathway, thus resulting in the reversion of drug resistance ${ }^{[123]}$. Moreover, Schott et al. ${ }^{[124]}$ showed that residual BCSC subpopulation is insensitive to docetaxel alone. However, in tumor-derived xenografts, GSI treatment (MK-0752), together with docetaxel, by affecting both NICD and HES1 expression, results in reduced BCSC population. In this study, the authors also included 30 patients with relapsed BC disease after treatment with anthracyclines (NCT00645333) and demonstrated that multiples cycles of GSI treatments produces a reduction in ALDH+ $\mathrm{BC}$ cells, as well as a partial response in 11 patients, finally suggesting that additional treatment cycles are required to amplify BCSC reduction and tumor burden ${ }^{[124]}$.

In addition to GSI treatments, other approaches to inhibit Notch signaling have also been evaluated in clinical trials. Preliminary activity against Notch has been further demonstrated by using tarextumab, a firstclass anti-Notch $2 / 3$ antibody, in a recently completed phase I clinical trial for the treatment of advanced solid tumors (NCT01277146), including breast cancer. Gene expression assays confirmed the downregulation of BCSC markers along with Notch2 and Notch3 inhibition ${ }^{[125]}$, thus suggesting that tarextumab may be used in combination with other therapies that eradicate CSC population.

Both Notch1 and Notch3 are also involved in the self-renewal and maintenance of the CSC properties in OC (OCSCs) $)^{[126,127]}$. It has been shown that the expression of Notch1 is strongly associated with the 
expression of ALDH1, which in turn increased the proliferation of OCSCs and their spheroid formation ${ }^{[128]}$. Interestingly, the combined inhibition of Notch1 and ALDH1 obtained by using liposomal doxorubicin DOXIL $^{\bullet}$ and the anticancer compound withaferin A co-treatment produces a significant reduction in the tumorigenic functions of OCSCs. Therefore, the combination treatment elicits synergistic effects targeting OCSCs, thus suggesting an important potential approach to minimize the induction of Notch-dependent platinum resistance and recurrence of $\mathrm{OC}^{[128]}$.

In high grade serous OC, a link between Notch3 and ALDH1 has been reported, already recognized as important in tumor formation ${ }^{[129]}$ and drug resistance ${ }^{[130]}$. Interestingly, Kim et al. ${ }^{[131]}$ showed that the combined co-expression of Notch3 and ALDH1 observed in human OC tissues correlates with all poor prognosis parameters, advanced clinical stage, and chemo-resistance in OC.

Moreover, Notch inhibition in paclitaxel-resistant OC cells significantly led to a decrease in viability and migration while apoptosis increased. Notably, both Notch3 silencing and pan-Notch inhibition via GSI treatments are able to induce reduced self-renewal ability of the OCSCs, accompanied by a significant downregulation of stem cell markers, including ALDH1, CD44, CD133, and SOX2. Together, these findings demonstrate that Notch3-specific blocking inhibits OCSC activation and re-sensitizes paclitaxel-resistant OC cells to paclitaxel with an efficacy comparable to GSI treatments ${ }^{[132]}$. In keeping with these findings, another study showed that Notch3 expression is regulated by miR-136 in association with paclitaxel resistance. The authors demonstrated that low expression of miR-136 is correlated with poor prognostic clinico-pathological parameters in OC-bearing patients, while its over-expression is associated with a reduction of proliferation, CSC spheroid formation, and CSC markers expression and increased apoptosis of paclitaxel-resistant cells. Mechanistically, miR-136 is able to suppress Notch3 expression by directly binding to its 3-UTR, thus acting as a tumor suppressor. These observations provide evidence that the miR136-Notch3 signaling axis plays a critical role in the development of OC chemo-resistance, thus suggesting a potential novel therapeutic target for OC treatment ${ }^{[133]}$.

In this regard, McAuliffe et al. ${ }^{[134]}$ strongly supported the specific role of Notch3 signaling pathway in OCSC maintenance and tumor resistance to platinum using both in vitro and in vivo studies. They showed that inhibition of Notch3, by GSI or siRNA transfection, increases tumor sensitivity to platinum therapy but only the cisplatin/GSI combined treatments may be effective in targeting OCSCs, thus being critical for tumor eradication, and finally improving the sensitivity of OC cells to cisplatin response via enhancing the cellular response to DNA damage ${ }^{[134]}$.

The nuclear orphan receptor NR2F6 expression is directly correlated with tumor progression, especially in epithelial ovarian cancer (EOC), but its role remains largely unclear. Consistently, Li et al. ${ }^{[135]}$ demonstrated the interaction between NR2F6 and Notch signaling, where it promotes the transcriptional activity of the Notch3 through the interaction with its promoter and the enrichment of histone acetylase p300 on this, thus inducing Notch3 signaling activation, which results in increased OCSC properties and promoting cisplatin resistance $^{[135]}$.

Jiang et al. ${ }^{[136]}$ also demonstrated that treatment with the specific GSI DAPT inhibits self-renewal and stemness development of OCSCs by downregulation of Oct4 and Sox2 marker proteins, required for their maintenance ${ }^{[136]}$ and the promotion of $\mathrm{EMT}^{[137]}$.

Moreover, it has been observed that the human follicle stimulating hormone (FSH) inhibits apoptosis in OC cells by positively regulating the Oct4 stem cell signaling pathway and induces OCSC expansion and 
cisplatin resistance through Oct4-mediated Notch upregulation. This suggested that the stimulation of FSHstem cells is strongly associated to Notch-dependent drug resistance in OC cells ${ }^{[138]}$.

Moreover, to prevent tumor recurrence, it has been observed that the Notch signaling pathway can be influenced by using different compounds, known for their ability to target other receptors involved in different signaling pathways. For instance, Notch can be downregulated by using the inhibitor poziotinib, a pan-human HER inhibitor, which is also able to inhibit the expression of target genes of Notch, such as cMYC, thereby suppressing OC stem cell growth ${ }^{[139]}$, while it can be strongly activated by galectin-3, a member of the lectin family. Galectin-3, by favoring Notch signaling, is able to regulate stemness of OC cells, spheroids formation, and their mobility, thus emphasizing that the Notch pathway may be considered at the intersection between CSCs and EMT processes, which are crucial in cancer drug resistance acquisition, as well as in cancer cell plasticity.

Interestingly, galectin-3 directly interacted with the intracellular domain of Notch1 (NICD1) and increased its nuclear translocation. Indeed, downregulation of galectin-3 reduced the levels of cleaved NICD1 and the transcription of the Notch target genes, Hes1 and Hey1. In addition, an increased expression of galectin-3 has been observed in OC patients at advanced stages compared to stages 1 or 2, thus suggesting its involvement in supporting stemness and drug resistance by affecting Notch1 cleavage $e^{[140]}$.

More recently, Islam et al. ${ }^{[141]}$ observed that the use of the natural compound eugenol, through downregulation of Notch and Hes1 expression, can effectively reverse chemo-resistance through the depletion of OCSCs in Notch1-dependent pathway.

Since various findings suggested a close relationship between drug resistance and Jagged $1 /$ Notch signaling, Jagged 1 has been found to be a possible target to overcome resistance ${ }^{[142]}$. Indeed, downregulation of Jagged 1 in the taxane-resistant OC cells increases docetaxel sensitivity of cells. In keeping with these data, Liu et al ${ }^{[143]}$ reported that GATA1, by binding directly to the ligand, represents the upstream regulatory factor controlling Jagged1-Notch dependent cancer stem cell progression and OC metastasis through enhancing migration, invasion, and EMT. These results confirm the role of Jagged 1 in enhancing OC stemness, EMT, and drug resistance through activating Notch signaling pathway ${ }^{[143]}$.

As described above, the crosstalk between hypoxia and Notch signaling pathways controls the development and maintenance of CSCs. It has been suggested that the Notch pathway is required for HIF-1 $\alpha$-induced maintenance of $\mathrm{CSCs}^{[92]}$. Seo et al. ${ }^{[144]}$ reported that the hypoxia/Notch-1/Sox2 signaling is also crucial for maintaining OCSCs and, taken together, can thereby serve as a candidate for novel anti-CSCs therapeutics. Furthermore, the association between hypoxia and Notch signaling promotes drug resistance and selfrenewal of OCSCs. Indeed, Notch signaling facilitates hypoxia-induced upregulation of Sox2, which induces drug resistance in CSCs through the upregulation of the $\mathrm{ABC}$ transporters, $\mathrm{ABCB} 1$ and $\mathrm{ABCG} 2$, commonly involved in the efflux of anticancer agents. Consequently, DAPT treatment abolishes hypoxia-mediated induction of OCSCs, thereby reversing drug resistance ${ }^{[144]}$.

CSCs have also been proposed to be responsible for high recurrence rate and chemo-resistance also in cervical carcinoma (CC ${ }^{[145]}$. Yang et al. ${ }^{[146]}$ observed an enrichment of the cervical CSC (CCSC) population and an increase in spheroid formation after cisplatin treatment. Interestingly, CCSCs display the upregulation of Notch expression, suggesting its specific correlation with cisplatin resistance also in CC. Indeed, the doxycycline-dependent inhibition of Notch blocks the proliferation and differentiation rate of CCSCs, bringing an enhancement in cisplatin therapy ${ }^{[146]}$. Moreover, the expression of the stemness markers 
Oct-4 and Sox-2, Notch1, and the Notch signaling components (ADAM-17, $\gamma$-secretase, and JAG1) is found to be significantly elevated in 5-fluorouracil (5-FU)-resistant CC cell lines. Currently, it has been demonstrated that ADAM 17 inhibition through the nano-formulation of Quinacrine (NQC) in 5-FU resistant CSCs leads to the reduction of their proliferation, thus inducing re-sensitization to the treatment $^{[147]}$.

Notably, it has been documented that the Notch pathway is involved not only in CSC-driven chemoresistance but also in the radio-resistance event. A recent study reported that Notch signaling is upregulated by its interaction with fused toes homolog (FTS) determining the maintenance of CSCs and spheroid formation upon irradiation of CC cells. The authors showed that the silencing of FTS increases radiosensitivity by blocking Notch1 activation ${ }^{[148]}$.

Concerning endometrial CSCs (ECSCs), it has been demonstrated that they acquire drug resistance due to high expression levels of CD133, a widely accepted biomarker for tumor-initiating cells. Indeed, CD133+ cells exhibited significant resistance to chemotherapy ${ }^{[149]}$. Studies indicated that the activation of Notch signaling pathway is a pivotal event in CD133+ cells as it promotes ECSC cell growth, proliferation, and selfrenewal while Notch inactivation can sensitize CD133+ cells to chemotherapy ${ }^{[150,151]}$. Furthermore, the molecular therapeutics targeting key biomarkers such as EGFR receptors showed some success in clinical trials, but the cancer stem cell-derived drug resistance hindered the drug effects ${ }^{[152]}$. Recently, Shang et al. ${ }^{[71]}$ found that Notch signaling is expressed in both CD133+ and CD133-cells. However, the activation of Notch signaling in $\mathrm{CD} 133+$ cells leads to a higher proliferation rate and lower apoptosis and results in targeted-therapy resistance, compared to CD133- cells. Findings from xenograft experiments further demonstrated that $\mathrm{CD} 133+$ cells are able to retain a higher tumorigenic capacity than their counterpart, thus indicating their tumor-initiating feature. In addition, Notch inhibition by DAPT combined with EGFR inhibitor (AG1478) treatment on EC cells displays ameliorative effects compared to DAPT or AG1478 treatments alone, thus reducing the $\mathrm{CD} 133+$ cells viability ${ }^{[7]}$.

Therefore, given the pivotal role of Notch signaling in the regulation of CSC activity in drug resistance (as summarized in Table 1), it might be useful to further investigate the regulatory mechanisms of Notchmediated resistance and evaluate whether inhibition of the Notch signaling cascade can be considered as a potential therapeutic approach to abrogate drug resistance in female cancers.

\section{NOTCH SIGNALING AND EMT}

The EMT is a process whereby epithelial cells acquire mesenchymal properties through the downregulation of cell adhesion molecules expression (i.e., E-cadherin) and the upregulation of mesenchymal markers expression (i.e., $\mathrm{N}$-cadherin), in order to gain migratory behaviors and invasive properties ${ }^{[153]}$. Increasing numbers of studies have not only suggested that EMT represents an essential process in normal embryonic development but also a significant mechanism involved in the progression of different cancer types ${ }^{[154]}$.

Most importantly, the acquisition of the EMT phenotype is related to chemo-resistance ${ }^{[155]}$, one of the most frequent causes of cancer mortality. Indeed, the targeting of key pathways which can regulate EMT may represent an effective treatment strategy.

Several studies have demonstrated that Notch over-expression is able to induce the loss of E-cadherin, while Notch inhibition increases $\mathrm{N}$-cadherin, thus suggesting that the Notch signaling pathway may represent a crucial regulatory mechanism for EMT ${ }^{[156]}$. Noteworthy, Notch signaling often interacts with other pathways in inducing EMT. Indeed, the authors also reported the presence of a crosstalk between Notch and TGF- $\beta$ 
Table 1. Effects of Notch-targeted therapeutics to reverse CSC-driven drug resistance. Summary of the pre-clinical and clinical studies

\begin{tabular}{|c|c|c|c|c|c|c|}
\hline Notch-targeted therapeutics & Target $^{\star}$ & Mechanism of action & Reverse resistance to & Model & $\begin{array}{l}\text { Cancer } \\
\text { context }\end{array}$ & Ref. \\
\hline mAb Notch1 & Notch1 & Decrease of mammosphere formation & Docetaxel (chemo-therapeutic agent) & Preclinical study: mice & Breast & {$[97]$} \\
\hline GSI ( $\gamma$-secretase inhibitor) & Jagged1/Notch signaling & Decrease of mammosphere formation & Tamoxifen (ER receptor inhibitor) & Preclinical study: mice & Breast & [100] \\
\hline AD01/ALM201 (FKBPL-based peptide) & DII4/Notch4 & Abrogation of BCSCs activity & Tamoxifen (ER receptor inhibitor) & Preclinical study: mice & Breast & [101] \\
\hline GSI ( $\gamma$-secretase inhibitor) & Jagged1/Notch signaling & Decrease of mammosphere formation & Lapatinib (EGFR/HER2 inhibitor) & Preclinical study: cell lines & Breast & [108] \\
\hline GSI ( $\gamma$-secretase inhibitor) & Jagged1/Notch1 & $\begin{array}{l}\text { Downregulation of HER2 expression in } \\
\text { mammosphere }\end{array}$ & Trastuzumab (HER2 inhibitor) & Preclinical study: cell lines & Breast & [109] \\
\hline shRNA Notch1 & Notch1 & $\begin{array}{l}\text { Downregulation of PTEN expression in } \\
\text { BCSCs }\end{array}$ & Trastuzumab (HER2 inhibitor) & Preclinical study: cell lines & Breast & [110] \\
\hline GSI-IX ( $\gamma$-secretase inhibitor) & Notch1 & Abrogation of BCSCs activity & BEZ235 + MLN128 (TORC1/2 inhibitor) & Preclinical study: cell lines & Breast & [116] \\
\hline GSI (PF-03084014) & Notch1 & Block of mammosphere formation & $\begin{array}{l}\text { MK-2206 (Akt inhibitor) + Bay11-7082) } \\
\text { IKK inhibitor }\end{array}$ & Preclinical study: cell lines & Breast & [120] \\
\hline Withaferin A (anticancer compound) & Notch1 & Reduction of OCSCs function & Doxorubicin (chemo-therapeutic agent) & Preclinical study: mice & Ovarian & [128] \\
\hline GSI/shRNA Notch3 & Notch3 & Inhibition of OCSCs activation & Paclitaxel (chemo-therapeutic agent) & Preclinical study: cell lines & Ovarian & [132] \\
\hline $\operatorname{miR}-136$ & Notch3 & Abrogate OCSCs activity & Paclitaxel (chemo-therapeutic agent) & Preclinical study: cell lines & Ovarian & [133] \\
\hline GSI ( $\gamma$-secretase inhibitor) & Notch3 & Abrogate OCSCs maintenance & Cisplatin (chemo-therapeutic agent) & Preclinical study: mice & Ovarian & [134] \\
\hline shRNA Galectin-3 & Notch1 & Downregulation of OCSCs stemness & $\begin{array}{l}\text { Paclitaxel + Cisplatin (chemo- } \\
\text { therapeutic agent) }\end{array}$ & Preclinical study: cell lines & Ovarian & [140] \\
\hline Eugenol (natural compound) & Notch1 & Depletion of OCSCs & Cisplatin (chemo-therapeutic agent) & Preclinical study: cell lines & Ovarian & [141] \\
\hline shRNA Jagged1 & Jagged1 & Downregulation of OCSCs stemness & Docetaxel (chemo-therapeutic agent) & Preclinical study: cell lines & Ovarian & [143] \\
\hline DAPT ( $\gamma$-secretase inhibitor) & Notch1 & $\begin{array}{l}\text { Abolishment of hypoxia-mediated } \\
\text { induction of OCSCs }\end{array}$ & Paclitaxel (chemo-therapeutic agent) & Preclinical study: cell lines & Ovarian & [144] \\
\hline Doxyclycine (antibiotic) & Notch1 & $\begin{array}{l}\text { Block of CCSCs proliferation and } \\
\text { differentiation rate }\end{array}$ & Cisplatin (chemo-therapeutic agent) & Preclinical study: mice & Cervical & [146] \\
\hline NQC (Quinacrine)/GW280264 & ADAM17/Notch signaling & Reduction of CCSCs proliferation & $\begin{array}{l}\text { 5-Fluorouracil (5-FU) (chemo- } \\
\text { therapeutic agent) }\end{array}$ & Preclinical study: cell lines & Cervical & [147] \\
\hline shFSH & Notch signaling & Abrogation of CCSCs maintenance & Irradiation & Preclinical study: cell lines & Cervical & [148] \\
\hline DAPT ( $\gamma$-secretase inhibitor) & Notch signaling & Reduction of ECSC viability & AG1478 (EGFR inhibitor) & Preclinical study: cell lines & Endometrial & [71] \\
\hline $\begin{array}{l}\text { GSI (PF-03084014) ( } \gamma \text {-secretase } \\
\text { inhibitor) }\end{array}$ & Notch signaling & Abrogation of BCSCs activity & Docetaxel (chemotherapeutic agent) & $\begin{array}{l}\text { Clinical trial: phase lb } \\
\text { (NCT01876251) }\end{array}$ & Breast & [122] \\
\hline GSI ( $\gamma$-secretase inhibitor) & Notch signaling & Reduction of BCSCs proliferation & $\begin{array}{l}\text { Anthracyclines (chemo-therapeutic } \\
\text { agent) }\end{array}$ & $\begin{array}{l}\text { Clinical trial: phase lb } \\
\text { (NCT00645333) }\end{array}$ & Breast & [124] \\
\hline GSI ( $\gamma$-secretase inhibitor) & Notch signaling & Downregulation of BCSCs markers & Tarextumab (mAb Notch2/3) & $\begin{array}{l}\text { Clinical trial: phase lb } \\
\text { (NCT01277146) }\end{array}$ & Breast & [125] \\
\hline
\end{tabular}

*Notch receptor or ligand involved, when specified. 
pathway. Particularly, they suggested that Notch could act downstream of the TGF- $\beta$ signaling, which is known to modulate the invasive and migratory properties of cancer cells. In addition, Kang et al. ${ }^{[157]}$ revealed that Notch-1 signaling triggers EMT in different types of cancers, and, conversely, its inactivation is responsible for the EMT suppression.

The two critical EMT-associated markers, Slug and Snail, are regulated by Notch signaling in $\mathrm{BC}^{[158,159]}$. Particularly, Slug seems to be a direct target gene of Notch $1^{[160]}$. Consistent with these findings, Notch2 is also able to upregulate some EMT-associated transcriptional regulators, i.e., Vimentin, Twist, Snail, and Slug, in basal type BC cells ${ }^{[161]}$. Jagged 1 has been shown to positively regulate Slug via Notch signaling activation, thus resulting in E-cadherin downregulation and EMT promotion ${ }^{[159,160,162]}$. Consistent with a previous report ${ }^{[93]}$, hypoxia-dependent activation of Notch signaling is also correlated with EMT in BC cells, as revealed by E-cadherin and $\beta$-catenin downregulation ${ }^{[158,163]}$. Mechanistically, Chen et al. ${ }^{[158]}$ revealed that the hypoxia-dependent Notch signaling activation is mediated by both HIF- $\alpha$ isoforms, which synergized with the transcriptional coactivator of Notch receptor, MAML1, in the transcription of Notch target genes.

Increasing evidence suggests that EMT is also associated with drug resistance in $\mathrm{BC}^{[164]}$ and that this process is partly responsible for chemo-resistance. Xiao et al. ${ }^{[164]}$ demonstrated that Notch1 significantly contributed to chemo-resistance in TNBC cells through the promotion of the expression of major vault protein (MVP), the main component of the vault complex ${ }^{[165]}$. MVP is involved in the export of drugs from the nucleus ${ }^{[166]}$ and is known to confer chemotherapy resistance in various tumor contexts ${ }^{[167]}$. The authors found that the intracellular domain of Notch1 is able to bind the promoter of MVP, thus inducing its transcription, and in turn promotes the AKT pathway activation. The activation of AKT resulted in EMT phenotype as well as in cisplatin and doxorubicin resistance. In the same tumor context, a Chinese study described a positive Notch 1 association with the expression of the melanoma cell adhesion molecule (MCAM), an EMT activator protein $^{[168]}$. In particular, the authors observed a time-dependent manner increased expression of both proteins after cisplatin treatment, even higher in cisplatin-resistant TNCB cells. This observation suggests the ability of Notch1 in promoting cisplatin chemo-resistance through MCAM-dependent EMT promotion in $\mathrm{TNBCs}^{[168]}$.

In keeping with these findings, Zhang et al. ${ }^{[123]}$ demonstrated that combined treatment of TNBC cells with GSI PF-03084014 and docetaxel is able to reverse the EMT phenotype and restore tumor chemo-sensitivity.

NumbL, the Numb homolog implicated in cell adhesion, migration, and division during central nervous system development ${ }^{[169]}$, has been shown to be a tumor suppressor protein in $\mathrm{BC}$ also for its negative regulation upon Notch signaling pathway ${ }^{[170,171]}$. In BC cells, the authors observed that NumbL downregulation is correlated with the activation of Notch pathway, further increasing the EMT-dependent transcription of Snail and Twist and inducing chemotherapy resistance. This explains why low expression of NumbL protein is observed in relapsed cancers, including $\mathrm{BC}^{[170]}$.

Gu et al. ${ }^{[172]}$ investigated Notch3 involvement in adriamycin-resistant MCF-7 BC cells. Notch3 expression is associated with chemo-sensitivity, while its downregulation has been shown to be involved in MCF-7 chemo-resistance. The authors showed that the Fos-related antigen 1 protein, a regulator involved in cell proliferation, differentiation, and transformation and EMT promotion, is negatively regulated by Notch 3 in tumor cells, thus revealing the onco-suppressive role of the receptor ${ }^{[172]}$. In keeping with these findings, it has been observed that Notch3 may negatively regulate $\mathrm{EMT}^{[173-176]}$, by acting, at least in part, via GATA-3 induction in $\mathrm{BC}$ cells ${ }^{[174]}$. This suggest that the involvement of Notch signaling is complex and contextdependent and further investigations are needed. 
The role of Notch signaling in EMT promotion is also largely demonstrated in OC. Alterations of Notch pathway are prevalent in $\mathrm{OC}^{[177]}$, where the signaling confers metastatic properties by the promotion of EMT, as confirmed by the upregulation of the mesenchymal markers and the downregulation of the epithelial ones ${ }^{[178]}$. Consequently, Notch targeting might represent a promising therapeutic strategy for the chemo-sensitivity restoration in OC context.

It has been demonstrated that thyroid hormone receptor interactor 13 (TRIP13), which is implicated in progression and metastasis of multiple cancers, acts as an oncogene in EOC development by the modulation of Notch signaling ${ }^{[179]}$. In particular, the authors observed that TRIP13 inhibition in OC cells, through the suppression of Notch pathway, finally leads to EMT suppression, thus supporting the Notch involvement in the acquisition of the mesenchymal properties ${ }^{[179]}$. In addition, Bocci et al.$^{[180]}$ also showed that the block of the Notch signaling inhibitor Numb can be an effective strategy to modulate Notch-driven EMT.

Some studies investigated the effects of the GSI DAPT on TGF- $\beta$-induced EMT, which is found in OC cells but is not expressed in normal ovarian epithelial cells ${ }^{[181,182]}$. DAPT treatment is able to reverse the TGF- $\beta$ induced EMT process, thus revealing the TGF- $\beta$ pathway's ability to control the OC mesenchymal phenotype via Notch signaling, finally favoring the chemo-resistance acquisition ${ }^{[181,182]}$. These findings contribute evidence that the Notch activation is partially required for the EMT induction by TGF- $\beta$ also in OC cells.

Notch signaling is also involved in the Rap1A-mediated EMT induction. The Ras-associated protein is able to promote the OC cell proliferation, migration, and invasion by activating Notch pathway, as well as ERK and MAPK pathways promotion and the EMT markers expression ${ }^{[183]}$. Indeed, it has been demonstrated that Notch signaling inhibition is able to revert the expression of those molecules, thus preventing the mesenchymal phenotype.

In cisplatin-resistant OC cells, a Chinese study revealed that Jagged 1 is able to interact with the JAK/STAT3 pathway by physically interacting with STAT3 and cooperating with the protein in supporting EMT, further reinforcing the invasion and migration abilities of platinum-resistant OC cells ${ }^{[184]}$. Indeed, the knockdown of Jagged 1 reverts EMT both in vitro and in vivo, thus reducing the cisplatin-resistant cells' abilities of invasion and migration ${ }^{[184]}$. Furthermore, a recent study reported that Numb knockdown, which in turn affected Notch pathway activation, inhibited cell proliferation, invasion, and migration, thus enhancing the antitumor effect of cisplatin in different OC cell lines ${ }^{[185]}$.

Notch3 seems to be specifically involved in the OC EMT-mediated chemo-resistance. Gupta et al. ${ }^{[178]}$ demonstrated that Notch3 activation in OVCA429 cells is responsible for the fibroblast-like morphology acquisition, the expression of EMT markers (i.e., Slug and Snail) and the decrease of E-cadherin expression on cell surface ${ }^{[178]}$. Notably, Notch3 expression is able to support OVCA429 resistance to carboplatin by the reduction of chemotherapy-induced apoptosis ${ }^{[178]}$.

The Notch signaling pathway also plays a pivotal role in CC development and progression, and it correlates with invasive and metastatic properties ${ }^{[186]}$. In particular, Wang et al. ${ }^{[72]}$ investigated the impact of Notch pathway on the survival, invasiveness, EMT, and chemo-resistance of CC cells; they observed that the expression of Notch2 was higher than in the normal HPV-16-immortalized human cervical epithelial cells CRL2614. Interestingly, the treatment with Notch inhibitor GSI RO4929097 is able to impair not only cancer cells proliferation but also the expression of the mesenchymal markers Snail, Twist, and N-cadherin, thus affecting their migration, invasion, and drug resistance ${ }^{[72]}$. 
In CC, radiotherapy represents one of the most common treatments for advanced tumor ${ }^{[187]}$, despite frequently resulting in recurrence. Several studies have demonstrated that the Notch receptor ligand Dll4 could be considered as a prognostic biomarker, thus predicting the pelvic lymph node metastasis in patients with $\mathrm{CC}^{[188]}$. In this study, Yang et al. ${ }^{[189]}$ observed that the Dll4 expression was higher in radiotherapyresistant $\mathrm{SiHa}$ CC cells in comparison with radiotherapy-sensitive CC Me-180 cells. In addition, they demonstrated that the Dll4 small interfering is able to inhibit the EMT and to reduce proliferation, invasion, and migration of CC cells, thus finally increasing CC radio-sensitivity.

Progestin treatment has been used as a conservative therapy for a long time in $\mathrm{EC}^{[190,191]}$, showing recurrence in more than half of treated EC patients ${ }^{[192]}$. For the first time, Zhou et al.$^{[193]}$ demonstrated that EMT is also involved in progestin resistance of EC, which represents the main hormone treatment for this cancer. It has been demonstrated that dachshund homolog $1(\mathrm{DACH} 1)$ was a tumor suppressor in progestin-resistant Ishikawa PR EC cells because its overexpression was able to inhibit EMT and reverse drug resistance ${ }^{[193]}$. Interestingly, DACH1 regulated EMT by Notch1 pathway suppression, thus revealing how the Notch pathway is strongly involved in the regulation of EMT also in EC context, being ultimately responsible for therapy resistance.

As highlighted above, the Notch signal pathway can be considered a key regulator in the promotion of EMT, which is in turn involved in drug resistance in various cancer types, including female tumors (as summarized in Table 2). Indeed, its down-modulation may represent a novel approach for cancer treatment in order to overcome not only chemo-resistance but also other types of resistance, such as resistance to hormone-based treatments. However, much has not been investigated and there would be much to learn on this topic.

\section{NOTCH SIGNALING AND DRUG EFFLUX}

The human genome encodes 49 different ATP-binding cassette (ABC) transporters, grouped into seven subfamilies (from A to $G$ ) ${ }^{[194]}$. They are responsible for the intracellular levels of small molecules and are involved in physiological processes ${ }^{[195]}$. Notably, ABC transporters such as multidrug resistance protein 1 (MDR1/ABCB1), multidrug resistance-associated protein (MRP1/ABCC1), and breast cancer resistance protein $(B C R P / A B C G 2)$ are overexpressed in cancer cells ${ }^{[196]}$, and they can efflux anticancer agents, thereby leading to drug resistance ${ }^{[6]}$.

Several studies performed in various tumor contexts indicated that Notch signaling regulates $\mathrm{ABC}$ transporter transcription ${ }^{[197-199]}$.

Concerning female-specific malignancies, this relationship was investigated mainly in OC and BC (as summarized in Table 3). For instance, Park et al. ${ }^{[200]}$ demonstrated that Notch3 increases the expression of MDR1/ABCB1 in OC cell lines. Indeed, Notch3 knockdown led to the downregulation of MDR1/ABCB1, thus reversing carboplatin resistance ${ }^{[200]}$. Moreover, Zhang et al. ${ }^{[123]}$ evaluated the anti-tumor efficacy of the $\gamma$ -secretase inhibitor PF-03084014 in combination with docetaxel in TNBCs both in vitro and in vivo studies: the authors demonstrated that PF-03084014 improves taxane-based therapy by multiple mechanisms, among them the decrease of MDR1/ABCB1 and $\mathrm{ABCC} 2$ transporters $^{[123]}$.

Furthermore, ectopic expression of the intracellular domain of Notch1 (N1ICD) correlated to the increase of another $\mathrm{ABC}$ transporter (MRP1/ABCC1), both at mRNA and protein levels, in $\mathrm{BC}$ cell lines. The authors clearly demonstrated that N1ICD induces the transcription of MRP1/ABCC1 by interacting with $\mathrm{CBF} 1$ and its effects in promoting drug resistance by the induction of this transporter ${ }^{[201]}$. Consistent with 
Table 2. Effects of Notch-targeted therapeutics to reverse EMT-driven drug resistance. Summary of the pre-clinical studies

\begin{tabular}{|c|c|c|c|c|c|c|}
\hline $\begin{array}{l}\text { Notch-targeted } \\
\text { therapeutics }\end{array}$ & Target ${ }^{\star}$ & Mechanism of action & $\begin{array}{l}\text { Reverse resistance } \\
\text { to }\end{array}$ & Model & $\begin{array}{l}\text { Cancer } \\
\text { context }\end{array}$ & Ref. \\
\hline shRNA Notch1 & Notch1 & $\begin{array}{l}\text { Inhibition of the major vault protein } \\
\text { (MVP)-dependent AKT pathway } \\
\text { activation and EMT promotion }\end{array}$ & $\begin{array}{l}\text { Cisplatin + Doxorubicin } \\
\text { (chemo-therapeutic } \\
\text { agents) }\end{array}$ & $\begin{array}{l}\text { Preclinical } \\
\text { study: cell } \\
\text { lines }\end{array}$ & Breast & [164] \\
\hline shRNA Notch1 & Notch1 & $\begin{array}{l}\text { Inhibition of the melanoma cell adhesion } \\
\text { molecule (MCAM)-dependent EMT } \\
\text { promotion }\end{array}$ & $\begin{array}{l}\text { Cisplatin (chemo- } \\
\text { therapeutic agent) }\end{array}$ & $\begin{array}{l}\text { Preclinical } \\
\text { study: cell } \\
\text { lines }\end{array}$ & Breast & [168] \\
\hline $\begin{array}{l}\text { GSI PF-03084014 ( } \gamma- \\
\text { secretase inhibitor) }\end{array}$ & $\begin{array}{l}\text { Notch } \\
\text { signaling }\end{array}$ & Inhibition of EMT phenotype & $\begin{array}{l}\text { Docetaxel (chemo- } \\
\text { therapeutic agent) }\end{array}$ & $\begin{array}{l}\text { Preclinical } \\
\text { study: cell } \\
\text { lines }\end{array}$ & Breast & {$[123]$} \\
\hline shRNA Notch3 & Notch3 & $\begin{array}{l}\text { EMT phenotype revertion and } \\
\text { enhancement of chemo-therapy- } \\
\text { induced apoptosis }\end{array}$ & $\begin{array}{l}\text { Carboplatin (chemo- } \\
\text { therapeutic agent) }\end{array}$ & $\begin{array}{l}\text { Preclinical } \\
\text { study: cell } \\
\text { lines }\end{array}$ & Ovarian & [178] \\
\hline shRNA Jagged1 & Jagged1 & Inhibition of EMT phenotype & $\begin{array}{l}\text { Cisplatin (chemo- } \\
\text { therapeutic agent) }\end{array}$ & $\begin{array}{l}\text { Preclinical } \\
\text { study: mice }\end{array}$ & Ovarian & {$[184]$} \\
\hline shRNA Numb & $\begin{array}{l}\text { Notch } \\
\text { signaling }\end{array}$ & $\begin{array}{l}\text { Enhancement of chemo-therapy- } \\
\text { induced cell proliferation, invasion and } \\
\text { migration }\end{array}$ & $\begin{array}{l}\text { Cisplatin (chemo- } \\
\text { therapeutic agent) }\end{array}$ & $\begin{array}{l}\text { Preclinical } \\
\text { study: cell } \\
\text { lines }\end{array}$ & Ovarian & [185] \\
\hline shRNA DII4 & DII4 & Inhibition of EMT phenotype & Irradiation & $\begin{array}{l}\text { Preclinical } \\
\text { study: cell } \\
\text { lines }\end{array}$ & Cervical & [188] \\
\hline $\begin{array}{l}\text { Dachshund homolog } 1 \\
\text { (DACH1) overexpression }\end{array}$ & Notch1 & Inhibition of EMT phenotype & $\begin{array}{l}\text { Progestin (endocrine } \\
\text { therapy) }\end{array}$ & $\begin{array}{l}\text { Preclinical } \\
\text { study: cell } \\
\text { lines }\end{array}$ & Endometrial & {$[193]$} \\
\hline
\end{tabular}

*Notch receptor or ligand involved, when specified.

Table 3. Effects of Notch-targeted therapeutics to reverse drug efflux-dependent drug resistance. Summary of the pre-clinical studies

\begin{tabular}{|c|c|c|c|c|c|c|}
\hline $\begin{array}{l}\text { Notch-targeted } \\
\text { therapeutics }\end{array}$ & Target $^{\star}$ & Mechanism of action & Reverse resistance to & Model & $\begin{array}{l}\text { Cancer } \\
\text { context }\end{array}$ & Ref. \\
\hline $\begin{array}{l}\text { PF-03084014 ( } \gamma- \\
\text { secretase inhibitor) }\end{array}$ & $\begin{array}{l}\text { Notch } \\
\text { signaling }\end{array}$ & $\begin{array}{l}\text { Downregulation of MDR1/ABCB1 } \\
\text { and } A B C C 2 \text { transporters }\end{array}$ & $\begin{array}{l}\text { Docetaxel (chemo- } \\
\text { therapeutic agent) }\end{array}$ & $\begin{array}{l}\text { Preclinical study: } \\
\text { mice }\end{array}$ & Breast & {$[123]$} \\
\hline shRNA Notch3 & Notch3 & $\begin{array}{l}\text { Downregulation of MDR1/ABCB1 } \\
\text { transporter }\end{array}$ & $\begin{array}{l}\text { Carboplatin (chemo- } \\
\text { therapeutic agent) }\end{array}$ & $\begin{array}{l}\text { Preclinical study: } \\
\text { cell lines }\end{array}$ & Ovarian & [200] \\
\hline IncRNA MALAT1 & Notch1 & $\begin{array}{l}\text { Downregulation of MRP1/ABCC1 } \\
\text { transporter }\end{array}$ & $\begin{array}{l}\text { Cisplatin (chemo- } \\
\text { therapeutic agent) }\end{array}$ & $\begin{array}{l}\text { Preclinical study: } \\
\text { mice }\end{array}$ & Ovarian & [204] \\
\hline
\end{tabular}

*Notch receptor or ligand involved, when specified.

these findings, in a recent study, Zhang et al. ${ }^{[202]}$ demonstrated that the inhibitor of DNA-binding 4 (ID-4) protein sustains chemo-resistance in $\mathrm{BC}$ because it is positively associated with Notch 1 pathway by favoring CBF1-MRP1/ABCC1. Moreover, Kim et al. ${ }^{[203]}$ documented that Notch1 and MRP1/ABCC1 are upregulated after chemotherapy and their protein expression is positively correlated in BC clinical samples. Interestingly, a more recent study documented that Notch 1 is also connected to MRP1/ABCC 1 in OC, and it confers cisplatin resistance to OC cell lines ${ }^{[204]}$.

Given that it has been widely documented that $\mathrm{ABC}$ transporters are highly expressed in $\mathrm{CC}^{[205,206]}$ and $\mathrm{EC}^{[207]}$, it may be worthwhile investigating whether blocking $\mathrm{ABC}$ transporter function by Notch signaling inhibition could represent a potential approach to CC and EC treatment. 


\section{NOTCH SIGNALING AND TME}

The extracellular environment where cancer cells reside is generally characterized by hypoxia and low $\mathrm{pH}^{[208]}$ and consists of several cellular elements [i.e., cancer-associated fibroblasts (CAFs), immune cells including myeloid-derived suppressor cells (MDSCs), tumor-associated macrophages (TAMs), ECs, etc.] and non-cellular ones [i.e., cytokines, chemokines, extracellular matrix (ECM), etc.], collectively known as the $\mathrm{TME}^{[200]}$.

Notably, given that TME is a dynamic and often-changing network which influences and favors cancer cells, more and more studies are investigating how the TME is involved in responsiveness or resistance to various drugs ${ }^{[210]}$. For instance, stromal cells in the TME interact directly with cancer cells, sustaining their growth and promoting hypoxia, acidosis, and oxidative stress, thus contributing to ECM remodeling to induce angiogenesis and mechanical stiffness ${ }^{[211]}$. Moreover, MDSCs and TAMs protect cancer cells from immune elimination ${ }^{[212,213]}$, and CAFs induce drug resistance by secreting cytokines, chemokines, and exosomes ${ }^{[214]}$. Therefore, since the TME plays a crucial role in cancer resistance to therapies, deepening the understanding of the underlying molecular mechanisms is a promising strategy to overcome drug resistance ${ }^{[215]}$.

In this scenario, Notch receptors are involved in every aspect of the $\mathrm{TME}^{[216,217]}$. In the following subsections, we describe their role in shaping the female cancer TME and the consequences of targeting them in a therapeutic perspective (as summarized in Table 4).

\section{Disrupting Notch-dependent tumor and stromal cell interactions to overcome EMT- or CSC-driven drug resistance}

During tumor progression, it is well known that tumors co-evolve with the surrounding microenvironment ${ }^{[218]}$ and cancer cells recruit stromal cells, which in turn promote drug resistance and metastasis $^{[219]}$.

Among female-specific cancers, the Notch-mediated interaction between cancer and stromal cells has principally been studied in the $\mathrm{BC}$ context.

Xing et al ${ }^{[220]}$ found that $\mathrm{BC}$ brain metastatic cells secrete IL-1 $\beta$ to activate astrocytes via the NF- $\mathrm{kB}$ pathway. Consequently, cancer-activated astrocytes express Jagged1, which interacts with Notch1 in cancer cells to sustain CSCs in brain metastasis ${ }^{[220]}$. In line with these findings, Zheng et al. ${ }^{[221]}$ observed that chemotherapy induces the over-expression of Jagged 1 in the osteoblasts, thereby leading to the activation of Notch signaling in tumor cells. The authors developed a fully human monoclonal antibody against Jagged 1, named 15D11, to disrupt osteoblasts-tumor cells interaction and this was functional to reverse chemoresistance $^{[221]}$. The role of Jagged 1 in activating Notch signaling was also studied in OC: it has been shown that endothelial cells activate Notch3 signaling in OC cells via Jagged1, and this interaction mediates chemo-resistance by sustaining PI3K/Akt and ERK pathways ${ }^{[22]}$.

Furthermore, some studies focused on the Notch pathway and CAFs crosstalk in BC. Overall, on the one hand, Notch signaling is involved in regulating CAFs activation ${ }^{[223]}$, but, on the other hand, CAFs may activate Notch pathway in cancer cells leading to CSCs self-renewal and EMT ${ }^{[217]}$, thereby potentially favoring drug resistance, as described in the previous sections. Concerning the latter phenomenon, Tsuyada et al. ${ }^{[224]}$ documented a crosstalk circuit that involves STAT3 and Notch pathway. They showed that STAT3 binds the promoter of the cytokine CCL2 in CAFs, thereby augmenting the secretion of CCL2, which in turn promotes Notch1-dependent breast CSC self-renewal ${ }^{[224]}$. Moreover, it has been demonstrated that CAFs secrete the cytokine IL-6, which enhances Notch3 signaling and consequently invasiveness in 
Table 4. Effects of Notch-targeted therapeutics to reverse TME-driven drug resistance. Summary of the pre-clinical and clinical studies

\begin{tabular}{|c|c|c|c|c|c|c|}
\hline $\begin{array}{l}\text { Notch-targeted } \\
\text { therapeutics }\end{array}$ & Target $^{\star}$ & Mechanism of action & $\begin{array}{l}\text { Reverse resistance } \\
\text { to }\end{array}$ & Model & $\begin{array}{l}\text { Cancer } \\
\text { context }\end{array}$ & Ref. \\
\hline \multicolumn{7}{|c|}{ Tumor-stromal cell interaction } \\
\hline $\begin{array}{l}\text { 15D11 (mAb } \alpha- \\
\text { Jagged1) }\end{array}$ & $\begin{array}{l}\text { Jagged1/Notch } \\
\text { signaling }\end{array}$ & Reduction of bone metastasis & $\begin{array}{l}\text { Paclitaxel (chemo- } \\
\text { therapeutic agent) }\end{array}$ & Preclinical study: mice & Breast & [221] \\
\hline $\begin{array}{l}\text { DAPT ( } \gamma \text {-secretase } \\
\text { inhibitor) }\end{array}$ & Jagged1/Notch3 & $\begin{array}{l}\text { Inhibition of the expansion of } \\
\text { radiotherapy-resistant BCSCs } \\
\left(\mathrm{CD} 44^{+} \mathrm{CD} 24^{\text {low }}\right)\end{array}$ & Irradiation & Preclinical study: mice & Breast & [227] \\
\hline shRNA Notch3 & Notch3 & $\begin{array}{l}\text { Inhibition of the expansion of } \\
\text { hormonal therapey-resistant } \\
\text { BCSCs (CD133 }\end{array}$ & $\begin{array}{l}\text { Fulvestrant (ER } \\
\text { inhibitor) }\end{array}$ & $\begin{array}{l}\text { Preclinical study: cell } \\
\text { lines }\end{array}$ & Breast & [228] \\
\hline $\begin{array}{l}\text { GSI ( } \gamma \text {-secretase } \\
\text { inhibitor) }\end{array}$ & Jagged1/Notch3 & $\begin{array}{l}\text { Inhibition of the expansion of } \\
\text { chemo-resistant OC cells }\end{array}$ & $\begin{array}{l}\text { Cisplatin + Taxol } \\
\text { (chemo-therapeutic } \\
\text { agents) }\end{array}$ & $\begin{array}{l}\text { Preclinical study: cell } \\
\text { lines }\end{array}$ & Ovarian & [222] \\
\hline \multicolumn{7}{|c|}{ Tumor-immune cells interaction } \\
\hline $\begin{array}{l}\text { Ginsenoside Rg3 } \\
\text { (natural compound) }\end{array}$ & Notch signaling & $\begin{array}{l}\text { Inhibition of MDSC-induced } \\
\text { cancer stemness and EMT }\end{array}$ & Irradiation & $\begin{array}{l}\text { Preclinical study: cell } \\
\text { lines }\end{array}$ & Breast & [244] \\
\hline $\begin{array}{l}\text { RO4929097 }(\gamma- \\
\text { secretase inhibitor) }\end{array}$ & $\begin{array}{l}\text { Jagged1/Notch } \\
\text { signaling }\end{array}$ & $\begin{array}{l}\text { Inhibition of tumor-associated } \\
\text { macrophages M2 polarization }\end{array}$ & $\begin{array}{l}\text { Aromatase inhibitor } \\
\text { (ER inhibitor) }\end{array}$ & $\begin{array}{l}\text { Preclinical study: cell } \\
\text { lines }\end{array}$ & Breast & [245] \\
\hline \multicolumn{7}{|l|}{ Tumor vasculature } \\
\hline $\begin{array}{l}\text { ABT-165 (bsAb } \alpha- \\
\text { DII4/VEGF) }\end{array}$ & DII4 & $\begin{array}{l}\text { Disruption of functional tumor } \\
\text { vasculature }\end{array}$ & $\begin{array}{l}\text { Paclitaxel (chemo- } \\
\text { therapeutic agent) }\end{array}$ & Preclinical study: mice & Breast & [259] \\
\hline $\begin{array}{l}\text { HB-32 (bsAb } \alpha- \\
\text { DII4/VEGF) }\end{array}$ & DII4 & $\begin{array}{l}\text { Disruption of functional tumor } \\
\text { vasculature }\end{array}$ & $\begin{array}{l}\text { Docetaxel (chemo- } \\
\text { therapeutic agent) }\end{array}$ & Preclinical study: mice & Breast & [260] \\
\hline $\begin{array}{l}\text { REGN421 (mAb } \alpha- \\
\text { DII4) }\end{array}$ & DII4 & $\begin{array}{l}\text { Disruption of functional tumor } \\
\text { vasculature }\end{array}$ & $\begin{array}{l}\text { Aflibercept (VEGF } \\
\text { inhibitor) }\end{array}$ & Preclinical study: mice & Ovarian & [262] \\
\hline $\begin{array}{l}\text { REGN421 (mAb } \alpha- \\
\text { DII4) }\end{array}$ & DII4 & $\begin{array}{l}\text { Disruption of functional tumor } \\
\text { vasculature }\end{array}$ & $\begin{array}{l}\text { Aflibercept (VEGF } \\
\text { inhibitor) }\end{array}$ & Preclinical study: mice & Ovarian & [263] \\
\hline $\begin{array}{l}\text { Endostar } \\
\text { (recombinant human } \\
\text { endostatin) }\end{array}$ & DII4 & $\begin{array}{l}\text { Restoration of vascular } \\
\text { homeostasis }\end{array}$ & $\begin{array}{l}\text { Cisplatin + Paclitaxel } \\
\text { (chemo-therapeutic } \\
\text { agents) }\end{array}$ & Clinical study & Cervical & [266] \\
\hline $\begin{array}{l}\text { Demcizumab (mAb } \alpha- \\
\text { Dll4) }\end{array}$ & DII4 & $\begin{array}{l}\text { Disruption of functional tumor } \\
\text { vasculature }\end{array}$ & $\begin{array}{l}\text { Paclitaxel (chemo- } \\
\text { therapeutic agent) }\end{array}$ & $\begin{array}{l}\text { Clinical trial: phase lb } \\
\text { (NCT01952249) }\end{array}$ & Ovarian & [267] \\
\hline $\begin{array}{l}\text { Navicixumab (bsAb } \alpha- \\
\text { Dll4/VEGF) }\end{array}$ & DII4 & $\begin{array}{l}\text { Disruption of functional tumor } \\
\text { vasculature }\end{array}$ & $\begin{array}{l}\text { Paclitaxel (chemo- } \\
\text { therapeutic agent) }\end{array}$ & $\begin{array}{l}\text { Clinical trial: phase lb } \\
\text { (NCT03030287) }\end{array}$ & Ovarian & [268] \\
\hline
\end{tabular}

*Notch receptor or ligand, when specified.

ER $\alpha$-positive BC models. Indeed, IL-6 exposure leads to the chronic STAT3 phosphorylation, which induces the transcription of Notch3 receptor ${ }^{[225]}$. In both cases, CAFs act in a paracrine manner, but they can act also via cell-cell interactions: in particular, Pelon et al. ${ }^{[226]}$ reported that Notch1, Notch2, and Notch3 are upregulated in a specific subset of CAFs which promote BC cell invasion in a 3D model.

Interestingly, two studies reported that CAFs promote the upregulation of Notch3 signaling followed by the expansion of therapy resistant breast CSCs through either Jagged1-Notch3 interaction ${ }^{[227]}$ or CAF-derived microvesicles $^{[227,228]}$, thus pinpointing that Notch signaling may be targeted to overcome stroma-mediated resistance in BC. Notably, Boelens et al. ${ }^{[227]}$ observed that the paracrine activation of STAT1 increases the transcription of Notch target genes, thus suggesting that anti-Notch-based therapies may be hindered by the activation of different pathways which converge on the same substrates.

These observations highlight the potential benefits of investigating the Notch-mediated crosstalk between tumor cells and the stroma not only in $\mathrm{BC}$ context but also in other female malignancies since recent findings underpin the emerging role of stromal cells in drug resistance also in $\mathrm{OC}^{[229,230]}, \mathrm{EC}^{[231]}$, and $\mathrm{CC}^{[232]}$. 


\section{Disrupting Notch-dependent tumor and immune cells interaction to overcome drug resistance}

It is well established that the interplay between tumor and immune cells in the TME influences immune surveillance and responsiveness to therapies ${ }^{[233]}$.

Notably, Notch signaling is a key regulator of the immune infiltrate within the $\mathrm{TME}^{[234]}$. Indeed, both myeloid and lymphoid lineages are affected by Notch pathway ${ }^{[23,236]}$. On the one hand, Notch signaling is involved in the thymic development of $\mathrm{T}$ cells ${ }^{[237]}$ and plays a pivotal role in CD8+ T-cell activation and effector functions ${ }^{[238,239]}$. On the other hand, Notch signaling is required for the expansion and activity of immunosuppressive cells, such as MDSCs ${ }^{[240]}$ and $\mathrm{TAMs}^{[241]}$. These contradictory findings imply that the function of Notch receptors in tumor immunity is dependent upon components of the TME.

Beyond its function in several subpopulations of the immune compartment, Notch signaling influences the crosstalk between immune and cancer cells, which may drive drug resistance.

Interestingly, emerging evidence suggests that MDSCs and TAMs, in addition to their canonical role in the immune system, are crucial players in TME-related drug resistance by secreting cytokines, chemokines, and growth factors or by interacting directly with tumor cells ${ }^{[210]}$. Concerning female malignancies, there are only a few recent examples of how Notch signaling is involved in the immune cells-mediated resistance in BC.

It has been shown that the expansion of MDSCs correlates with tumor burden of BC-bearing patients, and the alteration of MDSC-tumor interaction is considered a promising strategy to combat this disease $\mathrm{e}^{[242]}$. Consistently with this observation, Peng et al. ${ }^{[243]}$ demonstrated that MDSCs accelerate tumor progression and increase tumor incidence in NOD-scid IL2R $\gamma$ null (NSG) mice in vivo. To dissect the underlying molecular mechanism, they observed that MDSCs promote and sustain BCSCs by regulating the crosstalk between STAT3 and Notch signaling in tumor cells. Indeed, MDSCs secretes IL-6, which induces STAT3 phosphorylation, and activates Notch signaling, which enforces IL-6/STAT3 activation, thereby affecting cancer stemness. Interestingly, the inhibition of these two pathways decreased tumor incidence in $v i v o^{[243]}$.

More recently, Song et al. ${ }^{[244]}$ made a step forward linking Notch-mediated MDSC-tumor interaction to drug resistance. By testing the main active component extracted from ginseng ( $\mathrm{Rg} 3$ ), the authors documented that the natural compound effectively hampers MDSCs expansion, and this correlates with Notch and STAT3 signaling pathways' down-modulation, which in turn suppresses cancer stemness and EMT in vitro and in vivo. Moreover, they showed that Rg3 is able to reverse MDSC-related radio-resistance in $\mathrm{BC}$ cell lines co-cultured with MDSCs ${ }^{[24]}$. The above-mentioned studies reported that MDSCs induce Notch signaling in cancer cells to promote drug resistance. Conversely, Liu et al.$^{[245]}$ demonstrated that cancer cells shape the TME by inducing the polarization of TAMs towards the anti-inflammatory M2 phenotype. They documented that this polarization is induced by Jagged 1 upregulation in ER+ BC cells, and it contributes to the development of resistance to the treatments against ER receptor such as aromatase inhibitors ${ }^{[245]}$.

Collectively, the mechanisms through which Notch signaling and immune cells favor drug resistance must be elucidated, but these recent studies prove that it is an evolving field and may prompt further investigations. Nevertheless, given the different role of Notch signaling in the immune infiltrate, the evaluation of Notch-modulating agents should take into account the subpopulation of cells in the TME. 


\section{Disrupting Notch signaling in tumor vasculature to overcome anti-angiogenic therapy resistance and favor chemotherapy}

Female-specific cancers are frequently characterized by exacerbated angiogenesis, which is fundamental for nutrient and oxygen supply to tumor tissue ${ }^{[24]}$. Given that anti-angiogenic therapy has shown promising clinical efficacy, many ongoing clinical trials have been investigating the effects of angiogenesis inhibition in the $\mathrm{OC}, \mathrm{EC}, \mathrm{CC}^{[247]}$, and $\mathrm{BC}^{[248]}$ contexts.

In this scenario, VEGF signaling represents the main target, but the efficacy is limited by the nonresponsiveness or resistance to the therapy ${ }^{[249]}$. Multiple mechanisms are involved in the afore-mentioned refractoriness ${ }^{[250]}$, including redundancy of the angiogenic signals ${ }^{[251]}$, thereby highlighting the necessity of finding novel strategies to affect the compensatory angiogenic pathways.

Since growing evidence is unraveling the relationship between angiogenesis and Dll4/Notch signaling, Dll4 has emerged as a promising target ${ }^{[252-254]}$. Indeed, over the years, several studies documented that Dll4 inhibition has proved extremely fruitful to overcome anti-VEGF resistance due to the augmented observed effects when combined with anti-VEGF inhibitors ${ }^{[25-257]}$.

Concerning BC, it has been shown that endothelial cells are characterized by high Dll4 expression, and this correlates with adverse prognosis for BC-bearing patients ${ }^{[258]}$. Therefore, these findings pave the way for therapeutic strategies targeting both VEGF and Dll4 pathways. For instance, two independent research groups recently developed dual-specific antibodies targeting both Dll4 and VEGF (ABT-165 and HB-32), obtaining promising results in vitro and in vivo ${ }^{[259,260]}$.

Similarly, given that high expression of Dll4 in OC correlated with non-responsiveness to anti-VEGF therapy ${ }^{[26]}$, it has been proposed to also block both pathways in this tumor type. Kuhnert et al. ${ }^{[262]}$ evaluated the activity of the developed fully human IgG1 monoclonal antibody against Dll4 (REGN421) in OC xenograft models. They observed that REGN421 alone is able to reduce tumor angiogenesis through the disruption of juxtacrine Dll4-Notch1 interactions between endothelial and tumor cells, but the effects are magnified by VEGF blockade ${ }^{[262,263]}$.

Collectively, these data in OC and BC underpin that the simultaneous inhibition of VEGF and Dll4 is a promising therapeutic approach and may warrant further investigations also in the CC and EC contexts.

Notably, an increasing number of studies revealed that angiogenesis is connected to drug resistance ${ }^{[264]}$. Specifically, several studies conducted in female-specific malignancies proved that an effective antiangiogenic therapy via Notch signaling inhibition favored chemotherapy in $\mathrm{OC}^{[263,265]}$ and $\mathrm{BC}^{[259,260]}$ preclinical models.

It is worth noting that some interesting results were also obtained in the clinics.

Recently, a recombinant human endostatin (Endostar) was tested on CC-bearing patients in combination with paclitaxel and cisplatin. Since Endostar was developed as a multi-target anti-angiogenic agent, it augmented the cytotoxicity of the chemotherapeutic agents by restoring vascular homeostasis, which was consistent with Dll4 and VEGF inhibition ${ }^{[266]}$. Interestingly, Endostar is currently tested in combination with chemoradiotherapy on CC-bearing patients in two clinical trials in the initial phase (status: recruitment) (NCT04121975; NCT03622827). 
Moreover, demcizumab (OMP-21M18), an IgG2 humanized monoclonal antibody targeting Dll4, was tested in Phase Ib (NCT01952249) in combination with paclitaxel on platinum-resistant OC, and it produced a positive response ${ }^{[267]}$. Furthermore, a novel bispecific antibody against Dll4/VEGF, navicixumab (OMP-305B83), has completed Phase I (NCT03030287) $)^{[268]}$, and it showed antitumor activity in combination with paclitaxel in OC patients, thereby obtaining fast track designation by the FDA.

Overall, this therapeutic strategy needs further development, but it is undoubtedly effective against gynecological cancers.

\section{CHALLENGES AND FUTURE DIRECTIONS}

Many pre-clinical studies have been carried out to elucidate the molecular mechanisms of Notch-mediated drug resistance in female tumors. Although the possibility of manipulating a key regulator of tumoral, stromal, and immune compartments makes this pathway a promising candidate to cope with drug resistance, its inhibition may be challenging.

First, given that Notch receptors are active in healthy tissues, pan-Notch inhibition led to off-target effects in several clinical trials ${ }^{[269]}$. Therefore, research is moving towards Notch-specific targeted therapies to reduce normal tissue toxicity, as clearly described by Majumder et al. ${ }^{[270]}$. As a result, more efforts are required in the future to test these novel Notch-modulating agents in synergistic combination with current treatments to effectively tackle Notch-driven resistance.

Second, since Notch signaling is deeply interconnected with other pathways which work in concert to promote drug resistance ${ }^{[27]}$, Notch signaling modulation may be made ineffective by the activation of compensatory pathways. As a result, the dissection of the underlying crosstalks will be necessary to come closer to the above-mentioned goal.

Third, Notch signaling may act differently in cell subpopulations within the same tumor and TME, thereby adding a further layer of complexity. For instance, as mentioned above, Notch signaling plays a pivotal role in shaping tumor immunity, but it can promote a pro- or anti-tumor response, thus questioning the effects of unspecific Notch targeting. These findings underscore the need for selective delivery. In this scenario, nanocarriers may circumvent this obstacle to increase tissue/cell-specific targeting. Interestingly, GSIs and other Notch-modulating agents have begun to be encapsulated in nano-formulations in BC and OC preclinical models ${ }^{[272]}$, thus providing foundations for further studies.

To sum up, taking into account the above-mentioned evidence, further studies should be carried out to achieve higher efficacy and clinical translation of Notch targeting.

\section{CONCLUSION}

Development of resistance severely hampers therapy efficacy and decreases the survival of tumor-bearing patients, including women affected by female-specific cancers. Indeed, given that researchers and clinicians are continuously obliged to face this obstacle, over the past decades, a lot of effort has been put into dissecting this complex phenomenon. Emerging evidence proves the key role played by the evolutionary conserved Notch pathway. In the present review, we describe how Notch signaling contributes to several kinds of resistance, from chemo- and radio-resistance to hormone-based and targeted therapies in female malignancies. The preclinical results obtained in BC, OC, CC, and EC contexts suggest that Notch signaling inhibition can be an effective tool to counteract drug resistance. Nonetheless, given that Notch signaling is broadly involved in tumoral, stromal, and immune compartments, future studies need to focus even more 
on a way to obtain higher efficacy before translating into the clinics.

\section{DECLARATIONS}

\section{Authors' contributions}

Study Concept and design: Giuli MV

Drafting of the manuscript: Giuli MV, Mancusi A, Giuliani E

Critical revision of the manuscript: Screpanti I, Checquolo S

\section{Availability of data and materials}

Not applicable.

\section{Financial support and sponsorship}

Maria V. Giuli was supported by a AIRC fellowship for Italy.

\section{Conflicts of interest}

All authors declared that there are no conflicts of interest.

\section{Ethical approval and consent to participate}

Not applicable.

\section{Consent for publication}

Not applicable.

\section{Copyright}

(c) The Author(s) 2021.

\section{REFERENCES}

1. Torre LA, Islami F, Siegel RL, Ward EM, Jemal A. Global cancer in women: burden and trends. Cancer Epidemiol Biomarkers Prev 2017;26:444-57. DOI PubMed

2. Luque-Bolivar A, Pérez-Mora E, Villegas VE, Rondón-Lagos M. Resistance and overcoming resistance in breast cancer. Breast Cancer (Dove Med Press) 2020;12:211-29. DOI PubMed PMC

3. Pinato DJ, Graham J, Gabra H, Sharma R. Evolving concepts in the management of drug resistant ovarian cancer: dose dense chemotherapy and the reversal of clinical platinum resistance. Cancer Treat Rev 2013;39:153-60. DOI PubMed

4. Holohan C, Van Schaeybroeck S, Longley DB, Johnston PG. Cancer drug resistance: an evolving paradigm. Nat Rev Cancer 2013;13:714-26. DOI PubMed

5. Vasan N, Baselga J, Hyman DM. A view on drug resistance in cancer. Nature 2019;575:299-309. DOI PubMed PMC

6. Haider T, Pandey V, Banjare N, Gupta PN, Soni V. Drug resistance in cancer: mechanisms and tackling strategies. Pharmacol Rep 2020;72:1125-51. DOI PubMed

7. Bukowski K, Kciuk M, Kontek R. Mechanisms of multidrug resistance in cancer chemotherapy. Int J Mol Sci 2020;21:3233. DOI PubMed PMC

8. Giuli MV, Giuliani E, Screpanti I, Bellavia D, Checquolo S. Notch signaling activation as a Hallmark for triple-negative breast cancer subtype. J Oncol 2019;2019:8707053. DOI PubMed PMC

9. Orzechowska M, Anusewicz D, Bednarek AK. Functional gene expression differentiation of the notch signaling pathway in female reproductive tract tissues-A comprehensive review with analysis. Front Cell Dev Biol 2020;8:592616. DOI PubMed PMC

10. Druesne-Pecollo N, Touvier M, Barrandon E, et al. Excess body weight and second primary cancer risk after breast cancer: a systematic review and meta-analysis of prospective studies. Breast Cancer Res Treat 2012;135:647-54. DOI PubMed

11. Youlden DR, Cramb SM, Dunn NA, Muller JM, Pyke CM, Baade PD. The descriptive epidemiology of female breast cancer: an international comparison of screening, incidence, survival and mortality. Cancer Epidemiol 2012;36:237-48. DOI PubMed

12. Hortobagyi GN, de la Garza Salazar J, Pritchard K, et al; ABREAST Investigators. The global breast cancer burden: variations in epidemiology and survival. Clin Breast Cancer 2005;6:391-401. DOI PubMed

13. Allemani C, Weir HK, Carreira H, et al. Global surveillance of cancer survival 1995-2009: analysis of individual data for 25 676 887 patients from 279 population-based registries in 67 countries (CONCORD-2). Lancet 2015;385:977-1010. DOI PubMed PMC

14. Toriola AT, Colditz GA. Trends in breast cancer incidence and mortality in the United States: implications for prevention. Breast Cancer Res Treat 2013;138:665-73. DOI PubMed

15. Anastasiadi Z, Lianos GD, Ignatiadou E, Harissis HV, Mitsis M. Breast cancer in young women: an overview. Updates Surg 
2017;69:313-7. DOI PubMed

16. Anders CK, Hsu DS, Broadwater G, et al. Young age at diagnosis correlates with worse prognosis and defines a subset of breast cancers with shared patterns of gene expression. J Clin Oncol 2008;26:3324-30. DOI PubMed

17. Anderson WF, Chatterjee N, Ershler WB, Brawley OW. Estrogen receptor breast cancer phenotypes in the surveillance, epidemiology, and end results database. Breast Cancer Res Treat 2002;76:27-36. DOI PubMed

18. Cadoo KA, Fornier MN and Morris PG. Biological subtypes of breast cancer: current concepts and implications for recurrence patterns. Q J Nucl Med Mol Imaging 2013;57:312-21. PubMed

19. Morris PG, Murphy CG, Mallam D, et al. Limited overall survival in patients with brain metastases from triple negative breast cancer. Breast $J$ 2012;18:345-50. DOI PubMed

20. Morris GJ, Naidu S, Topham AK, et al. Differences in breast carcinoma characteristics in newly diagnosed African-American and Caucasian patients: a single-institution compilation compared with the National Cancer Institute's Surveillance, Epidemiology, and End Results database. Cancer 2007;110:876-84. DOI PubMed

21. Stevanovic A, Lee P, Wilcken N. Metastatic breast cancer. Aust Fam Physician 2006;35:309-12. PubMed

22. Colditz GA, Bohlke K. Priorities for the primary prevention of breast cancer. CA Cancer J Clin 2014;64:186-94. DOI PubMed

23. Ellis MJ, Suman VJ, Hoog J, et al. Ki67 proliferation index as a tool for chemotherapy decisions during and after neoadjuvant aromatase inhibitor treatment of breast cancer: results from the American College of Surgeons Oncology Group Z1031 Trial (Alliance). J Clin Oncol 2017;35:1061-9. DOI PubMed PMC

24. Benson AB 3rd, Schrag D, Somerfield MR, et al. American Society of Clinical Oncology recommendations on adjuvant chemotherapy for stage II colon cancer. J Clin Oncol 2004;22:3408-19. DOI PubMed

25. McDonald ES, Clark AS, Tchou J, Zhang P, Freedman GM. Clinical diagnosis and management of breast cancer. J Nucl Med 2016;57 Suppl 1:9S-16S. DOI PubMed

26. Fredholm H, Eaker S, Frisell J, Holmberg L, Fredriksson I, Lindman H. Breast cancer in young women: poor survival despite intensive treatment. PLoS One 2009;4:e7695. DOI PubMed PMC

27. Vargas AN. Natural history of ovarian cancer. Ecancermedicalscience 2014;8:465. DOI PubMed PMC

28. Reid BM, Permuth JB, Sellers TA. Epidemiology of ovarian cancer: a review. Cancer Biol Med 2017;14:9-32. DOI PubMed PMC

29. Siegel RL, Miller KD, Jemal A. Cancer statistics, 2016. CA Cancer J Clin 2016;66:7-30. DOI PubMed

30. Matulonis UA, Sood AK, Fallowfield L, Howitt BE, Sehouli J, Karlan BY. Ovarian cancer. Nat Rev Dis Primers 2016;2:16061. DOI PubMed PMC

31. Torre LA, Bray F, Siegel RL, Ferlay J, Lortet-Tieulent J, Jemal A. Global cancer statistics, 2012. CA Cancer J Clin 2015;65:87-108. DOI PubMed

32. Jayson GC, Kohn EC, Kitchener HC, Ledermann JA. Ovarian cancer. Lancet 2014;384:1376-88. DOI PubMed

33. Beral V, Hermon C, Peto R, Reeves G. Hormone therapy and ovarian cancer - Authors' reply. Lancet 2015;386:1038-9. DOI PubMed

34. Armstrong DK, Bundy B, Wenzel L, et al; Gynecologic Oncology Group. Intraperitoneal cisplatin and paclitaxel in ovarian cancer. $N$ Engl J Med 2006;354:34-43. DOI PubMed

35. Bray F, Ferlay J, Soerjomataram I, Siegel RL, Torre LA, Jemal A. Global cancer statistics 2018: GLOBOCAN estimates of incidence and mortality worldwide for 36 cancers in 185 countries. CA Cancer J Clin 2018;68:394-424. DOI PubMed

36. Ferlay J, Soerjomataram I, Dikshit R, et al. Cancer incidence and mortality worldwide: sources, methods and major patterns in GLOBOCAN 2012. Int $J$ Cancer 2015;136:E359-86. DOI PubMed

37. Jansen EEL, Zielonke N, Gini A, et al; EU-TOPIA consortium. Effect of organised cervical cancer screening on cervical cancer mortality in Europe: a systematic review. Eur J Cancer 2020;127:207-23. DOI PubMed

38. Waggoner SE. Cervical cancer. Lancet 2003;361:2217-25. DOI PubMed

39. Olorunfemi G, Ndlovu N, Masukume G, Chikandiwa A, Pisa PT, Singh E. Temporal trends in the epidemiology of cervical cancer in South Africa (1994-2012). Int J Cancer 2018;143:2238-49. DOI PubMed PMC

40. Villain P, Gonzalez P, Almonte M, et al. European code against cancer 4th edition: infections and cancer. Cancer Epidemiol 2015;39 Suppl 1:S120-38. DOI PubMed

41. de Sanjosé S, Diaz M, Castellsagué X, et al. Worldwide prevalence and genotype distribution of cervical human papillomavirus DNA in women with normal cytology: a meta-analysis. Lancet Infect Dis 2007;7:453-9. DOI PubMed

42. Moscicki AB, Schiffman M, Burchell A, et al. Updating the natural history of human papillomavirus and anogenital cancers. Vaccine 2012;30 Suppl 5:F24-33. DOI PubMed PMC

43. Maza M, Schocken CM, Bergman KL, Randall TC, Cremer ML. Cervical precancer treatment in low- and middle-income countries: a technology overview. J Glob Oncol 2017;3:400-8. DOI PubMed PMC

44. Cohen PA, Jhingran A, Oaknin A, Denny L. Cervical cancer. Lancet 2019;393:169-82. DOI PubMed

45. Marquina G, Manzano A, Casado A. Targeted agents in cervical cancer: beyond bevacizumab. Curr Oncol Rep 2018;20:40. DOI PubMed

46. De Angelis R, Sant M, Coleman MP, et al. Cancer survival in Europe 1999-2007 by country and age: results of EUROCARE-5-a population-based study. Lancet Oncol 2014;15:23-34. DOI PubMed

47. El Mistiri M, Salati M, Marcheselli L, et al. Cancer incidence, mortality, and survival in Eastern Libya: updated report from the Benghazi Cancer Registry. Ann Epidemiol 2015;25:564-8. DOI PubMed

48. Arnold M, Pandeya N, Byrnes G, et al. Global burden of cancer attributable to high body-mass index in 2012: a population-based study. Lancet Oncol 2015;16:36-46. DOI PubMed PMC 
49. Cook LS, Kmet LM, Magliocco AM, Weiss NS. Endometrial cancer survival among U.S. black and white women by birth cohort. Epidemiology 2006;17:469-72. DOI PubMed

50. Syeda S, Chen L, Hou JY, et al. Chemotherapy, radiation, or combination therapy for stage III uterine cancer. Obstet Gynecol 2019;134:17-29. DOI PubMed PMC

51. Brasseur K, Gévry N, Asselin E. Chemoresistance and targeted therapies in ovarian and endometrial cancers. Oncotarget 2017;8:4008-42. DOI PubMed PMC

52. Artavanis-Tsakonas S, Rand MD, Lake RJ. Notch signaling: cell fate control and signal integration in development. Science 1999;284:770-6. DOI PubMed

53. Blaumueller CM, Qi H, Zagouras P, Artavanis-tsakonas S. Intracellular cleavage of notch leads to a heterodimeric receptor on the plasma membrane. Cell 1997;90:281-91. DOI PubMed

54. Hori K, Sen A, Artavanis-Tsakonas S. Notch signaling at a glance. J Cell Sci 2013;126:2135-40. DOI PubMed PMC

55. Bray SJ. Notch signalling: a simple pathway becomes complex. Nat Rev Mol Cell Biol 2006;7:678-89. DOI PubMed

56. Suresh S, Irvine AE. The NOTCH signaling pathway in normal and malignant blood cell production. J Cell Commun Signal 2015;9:5-13. DOI PubMed PMC

57. D'Souza B, Miyamoto A, Weinmaster G. The many facets of Notch ligands. Oncogene 2008;27:5148-67. DOI PubMed PMC

58. Groot AJ, Vooijs MA. The role of Adams in Notch signaling. In: Reichrath J, Reichrath S, editors. Notch signaling in embryology and cancer. New York: Springer US; 2012. p. 15-36. DOI

59. Yang G, Zhou R, Zhou Q, et al. Structural basis of Notch recognition by human $\gamma$-secretase. Nature 2019;565:192-7. DOI PubMed

60. Tien AC, Rajan A, Bellen HJ. A Notch updated. J Cell Biol 2009;184:621-9. DOI PubMed PMC

61. Kitagawa M. Notch signalling in the nucleus: roles of Mastermind-like (MAML) transcriptional coactivators. $J$ Biochem 2016;159:287-94. DOI PubMed

62. Contreras-Cornejo H, Saucedo-Correa G, Oviedo-Boyso J, et al. The CSL proteins, versatile transcription factors and context dependent corepressors of the notch signaling pathway. Cell Div 2016;11:12. DOI PubMed PMC

63. Schwanbeck R, Martini S, Bernoth K, Just U. The Notch signaling pathway: molecular basis of cell context dependency. Eur J Cell Biol 2011;90:572-81. DOI PubMed

64. Siebel C, Lendahl U. Notch signaling in development, tissue homeostasis, and disease. Physiol Rev 2017;97:1235-94. DOI PubMed

65. Aster JC, Pear WS, Blacklow SC. The varied roles of notch in cancer. Annu Rev Pathol 2017;12:245-75. DOI PubMed PMC

66. Lobry C, Oh P, Aifantis I. Oncogenic and tumor suppressor functions of Notch in cancer: it's NOTCH what you think. J Exp Med 2011;208:1931-5. DOI PubMed PMC

67. Ranganathan P, Weaver KL, Capobianco AJ. Notch signalling in solid tumours: a little bit of everything but not all the time. Nat Rev Cancer 2011;11:338-51. DOI

68. Weng AP, Ferrando AA, Lee W, et al. Activating mutations of NOTCH1 in human T cell acute lymphoblastic leukemia. Science 2004;306:269-71. DOI PubMed

69. Braune EB, Seshire A, Lendahl U. Notch and Wnt dysregulation and its relevance for breast cancer and tumor initiation. Biomedicines 2018;6:101. DOI PubMed PMC

70. Groeneweg JW, Foster R, Growdon WB, Verheijen RH, Rueda BR. Notch signaling in serous ovarian cancer. J Ovarian Res 2014;7:95. DOI PubMed PMC

71. Shang C, Lang B, Meng LR. Blocking NOTCH pathway can enhance the effect of EGFR inhibitor through targeting CD133+ endometrial cancer cells. Cancer Biol Ther 2018;19:113-9. DOI PubMed PMC

72. Wang L, Dai G, Yang J, Wu W, Zhang W. Cervical cancer cell growth, drug resistance, and epithelial-mesenchymal transition are suppressed by y-secretase inhibitor RO4929097. Med Sci Monit 2018;24:4046-53. DOI PubMed PMC

73. Batlle E, Clevers H. Cancer stem cells revisited. Nat Med 2017;23:1124-34. DOI PubMed

74. Lytle NK, Barber AG, Reya T. Stem cell fate in cancer growth, progression and therapy resistance. Nat Rev Cancer 2018;18:669-80. DOI PubMed

75. Najafi M, Mortezaee K, Majidpoor J. Cancer stem cell (CSC) resistance drivers. Life Sci 2019;234:116781. DOI PubMed

76. Shibue T, Weinberg RA. EMT, CSCs, and drug resistance: the mechanistic link and clinical implications. Nat Rev Clin Oncol 2017;14:611-29. DOI PubMed PMC

77. Keyvani V, Farshchian M, Esmaeili SA, et al. Ovarian cancer stem cells and targeted therapy. J Ovarian Res 2019;12:120. DOI PubMed PMC

78. Li Y, Wang Z, Ajani JA, Song S. Drug resistance and Cancer stem cells. Cell Commun Signal 2021;19:19. DOI PubMed PMC

79. Abdullah LN, Chow EK. Mechanisms of chemoresistance in cancer stem cells. Clin Transl Med 2013;2:3. DOI PubMed PMC

80. Tanabe S, Quader S, Cabral H, Ono R. Interplay of EMT and CSC in cancer and the potential therapeutic strategies. Front Pharmacol 2020;11:904. DOI PubMed PMC

81. Yang Y, Li X, Wang T, Guo Q, Xi T, Zheng L. Emerging agents that target signaling pathways in cancer stem cells. J Hematol Oncol 2020;13:60. DOI PubMed PMC

82. Takebe N, Warren RQ, Ivy SP. Breast cancer growth and metastasis: interplay between cancer stem cells, embryonic signaling pathways and epithelial-to-mesenchymal transition. Breast Cancer Res 2011;13:211. DOI PubMed PMC

83. Muñoz-Galván S, Felipe-Abrio B, García-Carrasco M, et al. New markers for human ovarian cancer that link platinum resistance to the cancer stem cell phenotype and define new therapeutic combinations and diagnostic tools. J Exp Clin Cancer Res 2019;38:234. DOI PubMed PMC

84. Meisel CT, Porcheri C, Mitsiadis TA. Cancer stem cells, Quo Vadis? Cells 2020;9:1879. DOI PubMed PMC 
85. BeLow M, Osipo C. Notch signaling in breast cancer: a role in drug resistance. Cells 2020;9:2204. DOI PubMed PMC

86. Acar A, Simões BM, Clarke RB, Brennan K. A role for Notch signalling in breast cancer and endocrine resistance. Stem Cells Int 2016;2016:2498764. DOI PubMed PMC

87. Nedeljković M, Damjanović A. Mechanisms of chemotherapy resistance in triple-negative breast cancer-how we can rise to the challenge. Cells 2019;8:957. DOI PubMed PMC

88. Grudzien P, Lo S, Albain KS, et al. Inhibition of Notch signaling reduces the stem-like population of breast cancer cells and prevents mammosphere formation. Anticancer Res 2010;30:3853-67. PubMed

89. Harrison H, Farnie G, Howell SJ, et al. Regulation of breast cancer stem cell activity by signaling through the Notch4 receptor. Cancer Res 2010;70:709-18. DOI PubMed PMC

90. Suman S, Das TP, Damodaran C. Silencing NOTCH signaling causes growth arrest in both breast cancer stem cells and breast cancer cells. Br J Cancer 2013;109:2587-96. DOI PubMed PMC

91. Samanta D, Gilkes DM, Chaturvedi P, Xiang L, Semenza GL. Hypoxia-inducible factors are required for chemotherapy resistance of breast cancer stem cells. Proc Natl Acad Sci US A 2014;111:E5429-38. DOI PubMed PMC

92. Hajizadeh F, Okoye I, Esmaily M, et al. Hypoxia inducible factors in the tumor microenvironment as therapeutic targets of cancer stem cells. Life Sci 2019;237:116952. DOI PubMed

93. Yan Y, Liu F, Han L, et al. HIF-2 $\alpha$ promotes conversion to a stem cell phenotype and induces chemoresistance in breast cancer cells by activating Wnt and Notch pathways. J Exp Clin Cancer Res 2018;37:256. DOI PubMed PMC

94. Wang T, Fahrmann JF, Lee H, et al. JAK/STAT3-regulated fatty acid $\beta$-oxidation is critical for breast cancer stem cell self-renewal and chemoresistance. Cell Metab 2018;27:1357. DOI PubMed PMC

95. Kim E, Kim M, Woo DH, et al. Phosphorylation of EZH2 activates STAT3 signaling via STAT3 methylation and promotes tumorigenicity of glioblastoma stem-like cells. Cancer Cell 2013;23:839-52. DOI PubMed PMC

96. Yang Q, Zhao S, Shi Z, et al. Chemotherapy-elicited exosomal miR-378a-3p and miR-378d promote breast cancer stemness and chemoresistance via the activation of EZH2/STAT3 signaling. J Exp Clin Cancer Res 2021;40:120. DOI PubMed PMC

97. Qiu M, Peng Q, Jiang I, et al. Specific inhibition of Notch1 signaling enhances the antitumor efficacy of chemotherapy in triple negative breast cancer through reduction of cancer stem cells. Cancer Lett 2013;328:261-70. DOI PubMed

98. Rustighi A, Zannini A, Tiberi L, et al. Prolyl-isomerase Pin1 controls normal and cancer stem cells of the breast. EMBO Mol Med 2014;6:99-119. DOI PubMed PMC

99. Rodriguez D, Ramkairsingh M, Lin X, Kapoor A, Major P, Tang D. The central contributions of breast cancer stem cells in developing resistance to endocrine therapy in estrogen receptor (ER)-positive breast cancer. Cancers (Basel) 2019;11:1028. DOI PubMed PMC

100. Simões BM, O'Brien CS, Eyre R, et al. Anti-estrogen resistance in human breast tumors is driven by JAG1-NOTCH4-dependent cancer stem cell activity. Cell Rep 2015;12:1968-77. DOI PubMed PMC

101. McClements L, Annett S, Yakkundi A, et al. FKBPL and its peptide derivatives inhibit endocrine therapy resistant cancer stem cells and breast cancer metastasis by downregulating DLL4 and Notch4. BMC Cancer 2019;19:351. DOI PubMed PMC

102. Diluvio G, Del Gaudio F, Giuli MV, et al. NOTCH3 inactivation increases triple negative breast cancer sensitivity to gefitinib by promoting EGFR tyrosine dephosphorylation and its intracellular arrest. Oncogenesis 2018;7:42. DOI PubMed PMC

103. Bousquet MS, Ratnayake R, Pope JL, et al. Seaweed natural products modify the host inflammatory response via Nrf2 signaling and alter colon microbiota composition and gene expression. Free Radic Biol Med 2020;146:306-23. DOI PubMed PMC

104. Chen Y, Fischer WH, Gill GN. Regulation of the ERBB-2 promoter by RBPJkappa and NOTCH. J Biol Chem 1997;272:14110-4. DOI PubMed

105. Takebe N, Harris PJ, Warren RQ, Ivy SP. Targeting cancer stem cells by inhibiting Wnt, Notch, and Hedgehog pathways. Nat Rev Clin Oncol 2011;8:97-106. DOI PubMed

106. Farnie G, Willan PM, Clarke RB, Bundred NJ. Combined inhibition of ErbB1/2 and Notch receptors effectively targets breast ductal carcinoma in situ (DCIS) stem/progenitor cell activity regardless of ErbB2 status. PLoS One 2013;8:e56840. DOI PubMed PMC

107. Magnifico A, Albano L, Campaner S, et al. Tumor-initiating cells of HER2-positive carcinoma cell lines express the highest oncoprotein levels and are sensitive to trastuzumab. Clin Cancer Res 2009;15:2010-21. DOI PubMed

108. Shah D, Wyatt D, Baker AT, et al. Inhibition of HER2 increases JAGGED1-dependent breast cancer stem cells: role for membrane JAGGED1. Clin Cancer Res 2018;24:4566-78. DOI PubMed PMC

109. Osipo C, Patel P, Rizzo P, et al. ErbB-2 inhibition activates Notch-1 and sensitizes breast cancer cells to a gamma-secretase inhibitor. Oncogene 2008;27:5019-32. DOI PubMed

110. Baker A, Wyatt D, Bocchetta M, et al. Notch-1-PTEN-ERK1/2 signaling axis promotes HER2+ breast cancer cell proliferation and stem cell survival. Oncogene 2018;37:4489-504. DOI PubMed

111. Loibl S, Darb-Esfahani S, Huober J, et al. Integrated analysis of PTEN and p4EBP1 protein expression as predictors for pCR in HER2-positive breast cancer. Clin Cancer Res 2016;22:2675-83. DOI PubMed

112. Steelman LS, Navolanic PM, Sokolosky ML, et al. Suppression of PTEN function increases breast cancer chemotherapeutic drug resistance while conferring sensitivity to mTOR inhibitors. Oncogene 2008;27:4086-95. DOI PubMed PMC

113. Revandkar A, Perciato ML, Toso A, et al. Inhibition of Notch pathway arrests PTEN-deficient advanced prostate cancer by triggering p27-driven cellular senescence. Nat Commun 2016;7:13719. DOI PubMed PMC

114. Steelman LS, Stadelman KM, Chappell WH, et al. Akt as a therapeutic target in cancer. Expert Opin Ther Targets 2008;12:1139-65. DOI PubMed

115. Choi HJ, Heo JH, Park JY, et al. A novel PI3K/mTOR dual inhibitor, CMG002, overcomes the chemoresistance in ovarian cancer. 
Gynecol Oncol 2019;153:135-48. DOI PubMed

116. Bhola NE, Jansen VM, Koch JP, et al. Treatment of triple-negative breast cancer with TORC1/2 inhibitors sustains a drug-resistant and Notch-dependent cancer stem cell population. Cancer Res 2016;76:440-52. DOI PubMed PMC

117. Ghasemi F, Sarabi PZ, Athari SS, Esmaeilzadeh A. Therapeutics strategies against cancer stem cell in breast cancer. Int J Biochem Cell Biol 2019;109:76-81. DOI PubMed

118. Song LL, Peng Y, Yun J, et al. Notch-1 associates with IKKalpha and regulates IKK activity in cervical cancer cells. Oncogene 2008;27:5833-44. DOI PubMed

119. Hao L, Rizzo P, Osipo C, et al. Notch-1 activates estrogen receptor-alpha-dependent transcription via IKKalpha in breast cancer cells. Oncogene 2010;29:201-13. DOI PubMed PMC

120. Hossain F, Sorrentino C, Ucar DA, et al. Notch signaling regulates mitochondrial metabolism and NF-kB activity in triple-negative breast cancer cells via IKK $\alpha$-dependent non-canonical pathways. Front Oncol 2018;8:575. DOI PubMed PMC

121. Mollen EWJ, Ient J, Tjan-Heijnen VCG, et al. Moving breast cancer therapy up a Notch. Front Oncol 2018;8:518. DOI PubMed PMC

122. Locatelli MA, Aftimos P, Dees EC, et al. Phase I study of the gamma secretase inhibitor PF-03084014 in combination with docetaxel in patients with advanced triple-negative breast cancer. Oncotarget 2017;8:2320-8. DOI PubMed PMC

123. Zhang CC, Yan Z, Zong Q, et al. Synergistic effect of the $\gamma$-secretase inhibitor PF-03084014 and docetaxel in breast cancer models. Stem Cells Transl Med 2013;2:233-42. DOI PubMed PMC

124. Schott AF, Landis MD, Dontu G, et al. Preclinical and clinical studies of gamma secretase inhibitors with docetaxel on human breast tumors. Clin Cancer Res 2013;19:1512-24. DOI PubMed PMC

125. Smith DC, Chugh R, Patnaik A, et al. A phase 1 dose escalation and expansion study of Tarextumab (OMP-59R5) in patients with solid tumors. Invest New Drugs 2019;37:722-30. DOI PubMed PMC

126. Ceccarelli S, Megiorni F, Bellavia D, Marchese C, Screpanti I, Checquolo S. Notch3 targeting: a novel weapon against ovarian cancer stem cells. Stem Cells Int 2019;2019:6264931. DOI PubMed PMC

127. Zhang L, Ma R, Gao M, et al. SNORA72 Activates the Notch1/c-Myc pathway to promote stemness transformation of ovarian cancer cells. Front Cell Dev Biol 2020;8:583087. DOI PubMed PMC

128. Kakar SS, Worth CA, Wang Z, Carter K, Ratajczak M, Gunjal P. DOXIL when combined with Withaferin A (WFA) targets ALDH1 positive cancer stem cells in ovarian cancer. J Cancer Stem Cell Res 2016;4:e1002. DOI PubMed PMC

129. Li Y, Chen T, Zhu J, Zhang H, Jiang H, Sun H. High ALDH activity defines ovarian cancer stem-like cells with enhanced invasiveness and EMT progress which are responsible for tumor invasion. Biochem Biophys Res Commun 2018;495:1081-8. DOI PubMed

130. Silva IA, Bai S, McLean K, et al. Aldehyde dehydrogenase in combination with CD133 defines angiogenic ovarian cancer stem cells that portend poor patient survival. Cancer Res 2011;71:3991-4001. DOI PubMed PMC

131. Kim MJ, Kim AR, Jeong JY, et al. Correlation of ALDH1 and Notch3 expression: clinical implication in ovarian carcinomas. $J$ Cancer 2017;8:3331-42. DOI PubMed PMC

132. Kang H, Jeong JY, Song JY, et al. Notch3-specific inhibition using siRNA knockdown or GSI sensitizes paclitaxel-resistant ovarian cancer cells. Mol Carcinog 2016;55:1196-209. DOI PubMed

133. Jeong JY, Kang H, Kim TH, et al. MicroRNA-136 inhibits cancer stem cell activity and enhances the anti-tumor effect of paclitaxel against chemoresistant ovarian cancer cells by targeting Notch3. Cancer Lett 2017;386:168-78. DOI PubMed

134. McAuliffe SM, Morgan SL, Wyant GA, et al. Targeting Notch, a key pathway for ovarian cancer stem cells, sensitizes tumors to platinum therapy. Proc Natl Acad Sci U S A 2012;109:E2939-48. DOI PubMed PMC

135. Li H, Zhang W, Niu C, et al. Nuclear orphan receptor NR2F6 confers cisplatin resistance in epithelial ovarian cancer cells by activating the Notch3 signaling pathway. Int J Cancer 2019;145:1921-34. DOI PubMed PMC

136. Jiang LY, Zhang XL, Du P, Zheng JH. $\gamma$-secretase inhibitor, DAPT inhibits self-renewal and stemness maintenance of ovarian cancer stem-like cells in vitro. Chin J Cancer Res 2011;23:140-6. DOI PubMed PMC

137. Liu L, Zhang J, Fang C, Zhang Z, Feng Y, Xi X. OCT4 mediates FSH-induced epithelial-mesenchymal transition and invasion through the ERK1/2 signaling pathway in epithelial ovarian cancer. Biochem Biophys Res Commun 2015;461:525-32. DOI PubMed

138. Zhang Z, Zhu Y, Lai Y, et al. Follicle-stimulating hormone inhibits apoptosis in ovarian cancer cells by regulating the OCT4 stem cell signaling pathway. Int J Oncol 2013;43:1194-204. DOI PubMed PMC

139. Lee H, Kim JW, Choi DK, et al. Poziotinib suppresses ovarian cancer stem cell growth via inhibition of HER4-mediated STAT5 pathway. Biochem Biophys Res Commun 2020;526:158-64. DOI PubMed

140. Kang HG, Kim DH, Kim SJ, et al. Galectin-3 supports stemness in ovarian cancer stem cells by activation of the Notch1 intracellular domain. Oncotarget 2016;7:68229-41. DOI PubMed PMC

141. Islam SS, Aboussekhra A. Sequential combination of cisplatin with eugenol targets ovarian cancer stem cells through the Notch-Hes 1 signalling pathway. J Exp Clin Cancer Res 2019;38:382. DOI PubMed PMC

142. Steg AD, Katre AA, Goodman B, et al. Targeting the notch ligand JAGGED1 in both tumor cells and stroma in ovarian cancer. Clin Cancer Res 2011;17:5674-85. DOI PubMed PMC

143. Liu Z, Zhu Y, Li F, Xie Y. GATA1-regulated JAG1 promotes ovarian cancer progression by activating Notch signal pathway. Protoplasma 2020;257:901-10. DOI PubMed

144. Seo EJ, Kim DK, Jang IH, et al. Hypoxia-NOTCH1-SOX2 signaling is important for maintaining cancer stem cells in ovarian cancer. Oncotarget 2016;7:55624-38. DOI PubMed PMC

145. Wang K, Zeng J, Luo L, et al. Identification of a cancer stem cell-like side population in the HeLa human cervical carcinoma cell 
line. Oncol Lett 2013;6:1673-80. DOI PubMed PMC

146. Yang B, Lu Y, Zhang A, et al. Correction: doxycycline induces apoptosis and inhibits proliferation and invasion of human cervical carcinoma stem cells. PLoS One 2015;10:e134201. DOI PubMed PMC

147. Nayak A, Das S, Nayak D, Sethy C, Narayan S, Kundu CN. Nanoquinacrine sensitizes 5-FU-resistant cervical cancer stem-like cells by down-regulating Nectin-4 via ADAM-17 mediated NOTCH deregulation. Cell Oncol (Dordr) 2019;42:157-71. DOI PubMed

148. Prabakaran DS, Muthusami S, Sivaraman T, Yu JR, Park WY. Silencing of FTS increases radiosensitivity by blocking radiationinduced Notch1 activation and spheroid formation in cervical cancer cells. Int J Biol Macromol 2019;126:1318-25. DOI PubMed

149. Dean M, Fojo T, Bates S. Tumour stem cells and drug resistance. Nat Rev Cancer 2005;5:275-84. DOI PubMed

150. Friel AM, Zhang L, Curley MD, et al. Epigenetic regulation of CD133 and tumorigenicity of CD133 positive and negative endometrial cancer cells. Reprod Biol Endocrinol 2010;8:147. DOI PubMed PMC

151. Liu J, Mao Z, Huang J, Xie S, Liu T, Mao Z. Blocking the NOTCH pathway can inhibit the growth of CD133-positive A549 cells and sensitize to chemotherapy. Biochem Biophys Res Commun 2014;444:670-5. DOI PubMed

152. Nishimura T, Nakamura K, Yamashita S, Ikeda S, Kigure K, Minegishi T. Effect of the molecular targeted drug, erlotinib, against endometrial cancer expressing high levels of epidermal growth factor receptor. BMC Cancer 2015;15:957. DOI PubMed PMC

153. Nieto MA, Huang RY, Jackson RA, Thiery JP. EMT: 2016. Cell 2016;166:21-45. DOI PubMed

154. Thiery JP, Lim CT. Tumor dissemination: an EMT affair. Cancer Cell 2013;23:272-3. DOI PubMed

155. Wang Z, Li Y, Kong D, et al. Acquisition of epithelial-mesenchymal transition phenotype of gemcitabine-resistant pancreatic cancer cells is linked with activation of the notch signaling pathway. Cancer Res 2009;69:2400-7. DOI PubMed PMC

156. Saad S, Stanners SR, Yong R, Tang O, Pollock CA. Notch mediated epithelial to mesenchymal transformation is associated with increased expression of the Snail transcription factor. Int J Biochem Cell Biol 2010;42:1115-22. DOI PubMed

157. Kang J, Kim E, Kim W, et al. Rhamnetin and cirsiliol induce radiosensitization and inhibition of epithelial-mesenchymal transition (EMT) by miR-34a-mediated suppression of Notch-1 expression in non-small cell lung cancer cell lines. $J$ Biol Chem 2013;288:27343-57. DOI PubMed PMC

158. Chen J, Imanaka N, Chen J, Griffin JD. Hypoxia potentiates Notch signaling in breast cancer leading to decreased E-cadherin expression and increased cell migration and invasion. Br J Cancer 2010;102:351-60. DOI PubMed PMC

159. Shao $\mathrm{S}$, Zhao X, Zhang $\mathrm{X}$, et al. Notch1 signaling regulates the epithelial-mesenchymal transition and invasion of breast cancer in a Slug-dependent manner. Mol Cancer 2015;14:28. DOI PubMed PMC

160. Leong KG, Niessen K, Kulic I, et al. Jagged1-mediated Notch activation induces epithelial-to-mesenchymal transition through Sluginduced repression of E-cadherin. J Exp Med 2007;204:2935-48. DOI PubMed PMC

161. Lee GH, Yoo KC, An Y, et al. FYN promotes mesenchymal phenotypes of basal type breast cancer cells through STAT5/NOTCH2 signaling node. Oncogene 2018;37:1857-68. DOI PubMed

162. Elzamy S, Ms AA, Kandeel W. The prognostic significance of androgen receptor and $\beta$-catenin immunohistochemical expression in urothelial carcinoma with and without detrusor muscle invasion from an Egyptian institution. Pol J Pathol 2018;69:234-42. DOI PubMed

163. Sahlgren C, Gustafsson MV, Jin S, Poellinger L, Lendahl U. Notch signaling mediates hypoxia-induced tumor cell migration and invasion. Proc Natl Acad Sci U S A 2008;105:6392-7. DOI PubMed PMC

164. Xiao YS, Zeng, Liang YK, et al. Major vault protein is a direct target of Notch1 signaling and contributes to chemoresistance in triple-negative breast cancer cells. Cancer Lett 2019;440-441:156-67. DOI PubMed

165. Scheffer GL, Wijngaard PL, Flens MJ, et al. The drug resistance-related protein LRP is the human major vault protein. Nat Med 1995;1:578-82. DOI PubMed

166. Han M, Lv Q, Tang XJ, et al. Overcoming drug resistance of MCF-7/ADR cells by altering intracellular distribution of doxorubicin via MVP knockdown with a novel siRNA polyamidoamine-hyaluronic acid complex. J Control Release 2012;163:136-44. DOI PubMed

167. Berger W, Steiner E, Grusch M, Elbling L, Micksche M. Vaults and the major vault protein: novel roles in signal pathway regulation and immunity. Cell Mol Life Sci 2009;66:43-61. DOI PubMed

168. Zeng, Liang YK, Xiao YS, et al. Inhibition of Notch1 reverses EMT and chemoresistance to cisplatin via direct downregulation of MCAM in triple-negative breast cancer cells. Int J Cancer 2020;147:490-504. DOI PubMed

169. Rasin MR, Gazula VR, Breunig JJ, et al. Numb and Numbl are required for maintenance of cadherin-based adhesion and polarity of neural progenitors. Nat Neurosci 2007;10:819-27. DOI PubMed

170. García-Heredia JM, Verdugo Sivianes EM, Lucena-Cacace A, Molina-Pinelo S, Carnero A. Numb-like (NumbL) downregulation increases tumorigenicity, cancer stem cell-like properties and resistance to chemotherapy. Oncotarget 2016;7:63611-28. DOI PubMed PMC

171. Spana EP, Doe CQ. Numb antagonizes Notch signaling to specify sibling neuron cell fates. Neuron 1996;17:21-6. DOI PubMed

172. Gu X, Lu C, He D, et al. Notch3 negatively regulates chemoresistance in breast cancers. Tumour Biol;2016:15825-33. DOI PubMed

173. Liang YK, Lin HY, Dou XW, et al. MiR-221/222 promote epithelial-mesenchymal transition by targeting Notch3 in breast cancer cell lines. NPJ Breast Cancer 2018;4:20. DOI PubMed PMC

174. Lin HY, Liang YK, Dou XW, et al. Notch3 inhibits epithelial-mesenchymal transition in breast cancer via a novel mechanism, upregulation of GATA-3 expression. Oncogenesis 2018;7:59. DOI PubMed PMC

175. Wen XF, Chen M, Wu Y, et al. Inhibitor of DNA binding 2 inhibits epithelial-mesenchymal transition via up-regulation of Notch3 in breast cancer. Transl Oncol 2018;11:1259-70. DOI PubMed PMC

176. Tan J, Zhang X, Xiao W, et al. N3ICD with the transmembrane domain can effectively inhibit EMT by correcting the position of 
tight/adherens junctions. Cell Adh Migr 2019;13:203-18. DOI PubMed PMC

177. Jung SG, Kwon YD, Song JA, et al. Prognostic significance of Notch 3 gene expression in ovarian serous carcinoma. Cancer Sci 2010;101:1977-83. DOI PubMed

178. Gupta N, Xu Z, El-Sehemy A, Steed H, Fu Y. Notch3 induces epithelial-mesenchymal transition and attenuates carboplatin-induced apoptosis in ovarian cancer cells. Gynecol Oncol 2013;130:200-6. DOI PubMed

179. Zhou XY, Shu XM. TRIP13 promotes proliferation and invasion of epithelial ovarian cancer cells through Notch signaling pathway. Eur Rev Med Pharmacol Sci 2019;23:522-9. DOI PubMed

180. Bocci F, Jolly MK, Tripathi SC, et al. Numb prevents a complete epithelial-mesenchymal transition by modulating Notch signalling. J R Soc Interface 2017;14:20170512. DOI PubMed PMC

181. Pazos MC, Abramovich D, Bechis A, et al. Gamma secretase inhibitor impairs epithelial-to-mesenchymal transition induced by TGF$\beta$ in ovarian tumor cell lines. Mol Cell Endocrinol 2017;440:125-37. DOI PubMed

182. Zhou J, Jain S, Azad AK, et al. Notch and TGFß form a positive regulatory loop and regulate EMT in epithelial ovarian cancer cells. Cell Signal 2016;28:838-49. DOI PubMed

183. Lu L, Wang J, Wu Y, Wan P, Yang G. Rap1A promotes ovarian cancer metastasis via activation of ERK/p38 and notch signaling. Cancer Med 2016;5:3544-54. DOI PubMed PMC

184. Yang J, Xing H, Lu D, et al. Role of Jagged1/STAT3 signalling in platinum-resistant ovarian cancer. J Cell Mol Med 2019;23:400518. DOI PubMed PMC

185. Liu Z, Qi S, Fu Y, et al. NUMB knockdown enhanced the anti-tumor role of cisplatin on ovarian cancer cells by inhibiting cell proliferation and epithelial-mesenchymal transition. Translational Cancer Research 2019;8:379-88. DOI

186. Bajaj J, Maliekal TT, Vivien E, et al. Notch signaling in CD66+ cells drives the progression of human cervical cancers. Cancer Res 2011;71:4888-97. DOI PubMed

187. Powell ME. Modern radiotherapy and cervical cancer. Int J Gynecol Cancer 2010;20:S49-51. DOI PubMed

188. Yang S, Liu Y, Xia B, et al. DLL4 as a predictor of pelvic lymph node metastasis and a novel prognostic biomarker in patients with early-stage cervical cancer. Tumour Biol 2016;37:5063-74. DOI PubMed

189. Yang SS, Yu DY, Du YT, et al. Inhibition of Delta-like Ligand 4 enhances the radiosensitivity and inhibits migration in cervical cancer via the reversion of epithelial-mesenchymal transition. Cancer Cell Int 2020;20:344. DOI PubMed PMC

190. Ethier JL, Desautels DN, Amir E, MacKay H. Is hormonal therapy effective in advanced endometrial cancer? Gynecol Oncol 2017;147:158-66. DOI PubMed

191. Ramirez PT, Frumovitz M, Bodurka DC, Sun CC, Levenback C. Hormonal therapy for the management of grade 1 endometrial adenocarcinoma: a literature review. Gynecol Oncol 2004;95:133-8. DOI PubMed

192. Yahata T, Aoki Y, Tanaka K. Prediction of myometrial invasion in patients with endometrial carcinoma: comparison of magnetic resonance imaging, transvaginal ultrasonography, and gross visual inspection. Eur J Gynaecol Oncol 2007;28:193-5. PubMed

193. Zhou Q, Li W, Kong D, et al. DACH1 suppresses epithelial to mesenchymal transition (EMT) through Notch1 pathway and reverses progestin resistance in endometrial carcinoma. Cancer Med 2019;8:4380-8. DOI PubMed PMC

194. Vasiliou V, Vasiliou K, Nebert DW. Human ATP-binding cassette (ABC) transporter family. Hum Genomics 2009;3:281-90. DOI PubMed PMC

195. Robey RW, Pluchino KM, Hall MD, Fojo AT, Bates SE, Gottesman MM. Revisiting the role of ABC transporters in multidrugresistant cancer. Nat Rev Cancer 2018;18:452-64. DOI PubMed PMC

196. Housman G, Byler S, Heerboth S, et al. Drug resistance in cancer: an overview. Cancers (Basel) 2014;6:1769-92. DOI PubMed PMC

197. Wang Z, Ravula R, Cao M, Chow M, Huang Y. Transporter-mediated multidrug resistance and its modulation by Chinese medicines and other herbal products. Curr Drug Discov Technol 2010;7:54-66. DOI PubMed

198. Liu YP, Liao WC, Ger LP, et al. Carboxyl-terminal modulator protein positively regulates Akt phosphorylation and acts as an oncogenic driver in breast cancer. Cancer Res 2013;73:6194-205. DOI PubMed

199. Abbasifarid E, Sajjadi-Jazi SM, Beheshtian M, Samimi H, Larijani B, Haghpanah V. The role of ATP-binding cassette transporters in the chemoresistance of anaplastic thyroid cancer: a systematic review. Endocrinology 2019;160:2015-23. DOI PubMed

200. Park JT, Chen X, Tropè CG, Davidson B, Shih IeM, Wang TL. Notch3 overexpression is related to the recurrence of ovarian cancer and confers resistance to carboplatin. Am J Pathol 2010;177:1087-94. DOI PubMed PMC

201. Cho S, Lu M, He X, et al. Notch1 regulates the expression of the multidrug resistance gene ABCC1/MRP1 in cultured cancer cells. Proc Natl Acad Sci U S A 2011;108:20778-83. DOI PubMed PMC

202. Zhang X, Gu G, Song L, et al. ID4 promotes breast cancer chemotherapy resistance via CBF1-MRP1 pathway. J Cancer 2020;11:3846-57. DOI PubMed PMC

203. Kim B, Stephen SL, Hanby AM, et al. Chemotherapy induces Notch1-dependent MRP1 up-regulation, inhibition of which sensitizes breast cancer cells to chemotherapy. BMC Cancer 2015;15:634. DOI PubMed PMC

204. Bai L, Wang A, Zhang Y, Xu X, Zhang X. Knockdown of MALAT1 enhances chemosensitivity of ovarian cancer cells to cisplatin through inhibiting the Notch1 signaling pathway. Exp Cell Res 2018;366:161-71. DOI PubMed

205. Wagner W, Kania KD, Blauz A, Ciszewski WM. The lactate receptor (HCAR1/GPR81) contributes to doxorubicin chemoresistance via ABCB1 transporter up-regulation in human cervical cancer HeLa cells. J Physiol Pharmacol 2017;68:555-64. PubMed

206. Murahari M, Prakash KV, Peters GJ, Mayur YC. Acridone-pyrimidine hybrids- design, synthesis, cytotoxicity studies in resistant and sensitive cancer cells and molecular docking studies. Eur J Med Chem 2017;139:961-81. DOI PubMed

207. Terek MC, Zekioglu O, Sendag F, Akercan F, Ozsaran A, Erhan Y. MDR1 gene expression in endometrial carcinoma. Int J Gynecol 
Cancer 2003;13:673-7. DOI PubMed

208. Parks SK, Mazure NM, Counillon L, Pouysségur J. Hypoxia promotes tumor cell survival in acidic conditions by preserving ATP levels. J Cell Physiol 2013;228:1854-62. DOI PubMed

209. Hanahan D, Weinberg RA. Hallmarks of cancer: the next generation. Cell 2011;144:646-74. DOI PubMed

210. Erin N, Grahovac J, Brozovic A, Efferth T. Tumor microenvironment and epithelial mesenchymal transition as targets to overcome tumor multidrug resistance. Drug Resist Updat 2020;53:100715. DOI PubMed

211. Maman S, Witz IP. A history of exploring cancer in context. Nat Rev Cancer 2018;18:359-76. DOI PubMed

212. Hui L, Li H, Lu G, et al. Low dose of bisphenol a modulates ovarian cancer gene expression profile and promotes epithelial to mesenchymal transition via canonical Wnt pathway. Toxicol Sci 2018;164:527-38. DOI PubMed

213. Lin Y, Xu J, Lan H. Tumor-associated macrophages in tumor metastasis: biological roles and clinical therapeutic applications. $J$ Hematol Oncol 2019;12:76. DOI PubMed PMC

214. Shiga K, Hara M, Nagasaki T, Sato T, Takahashi H, Takeyama H. Cancer-associated fibroblasts: their characteristics and their roles in tumor growth. Cancers (Basel) 2015;7:2443-58. DOI PubMed PMC

215. Wu P, Gao W, Su M, et al. Adaptive mechanisms of tumor therapy resistance driven by tumor microenvironment. Front Cell Dev Biol 2021;9:641469. DOI PubMed PMC

216. Moore G, Annett S, McClements L, Robson T. Top Notch targeting strategies in cancer: a detailed overview of recent insights and current perspectives. Cells 2020;9:1503. DOI PubMed PMC

217. Meurette O. Shaping of the tumor microenvironment by Notch signaling. In: Birbrair A, editor. Tumor microenvironment. Cham: Springer International Publishing; 2020. p. 1-16. DOI

218. Bussard KM, Mutkus L, Stumpf K, Gomez-Manzano C, Marini FC. Tumor-associated stromal cells as key contributors to the tumor microenvironment. Breast Cancer Res 2016;18:84. DOI PubMed PMC

219. Fiori ME, Di Franco S, Villanova L, Bianca P, Stassi G, De Maria R. Cancer-associated fibroblasts as abettors of tumor progression at the crossroads of EMT and therapy resistance. Mol Cancer 2019;18:70. DOI PubMed PMC

220. Xing F, Kobayashi A, Okuda H, et al. Reactive astrocytes promote the metastatic growth of breast cancer stem-like cells by activating Notch signalling in brain. EMBO Mol Med 2013;5:384-96. DOI PubMed PMC

221. Zheng H, Bae Y, Kasimir-Bauer S, et al. Therapeutic antibody targeting tumor- and osteoblastic niche-derived Jagged 1 sensitizes bone metastasis to chemotherapy. Cancer Cell 2017;32:731-47.e6. DOI PubMed PMC

222. Hoarau-Véchot J, Touboul C, Halabi N, et al. Akt-activated endothelium promotes ovarian cancer proliferation through notch activation. J Transl Med 2019;17:194. DOI PubMed PMC

223. Liao Z, Tan ZW, Zhu P, Tan NS. Cancer-associated fibroblasts in tumor microenvironment - Accomplices in tumor malignancy. Cell Immunol 2019;343:103729. DOI PubMed

224. Tsuyada A, Chow A, Wu J, et al. CCL2 mediates cross-talk between cancer cells and stromal fibroblasts that regulates breast cancer stem cells. Cancer Res 2012;72:2768-79. DOI PubMed PMC

225. Studebaker AW, Storci G, Werbeck JL, et al. Fibroblasts isolated from common sites of breast cancer metastasis enhance cancer cell growth rates and invasiveness in an interleukin-6-dependent manner. Cancer Res 2008;68:9087-95. DOI PubMed

226. Pelon F, Bourachot B, Kieffer Y, et al. Cancer-associated fibroblast heterogeneity in axillary lymph nodes drives metastases in breast cancer through complementary mechanisms. Nat Commun 2020;11:404. DOI PubMed PMC

227. Boelens MC, Wu TJ, Nabet BY, et al. Exosome transfer from stromal to breast cancer cells regulates therapy resistance pathways. Cell 2014;159:499-513. DOI PubMed PMC

228. Sansone P, Berishaj M, Rajasekhar VK, et al. Evolution of cancer stem-like cells in endocrine-resistant metastatic breast cancers is mediated by stromal microvesicles. Cancer Res 2017;77:1927-41. DOI PubMed PMC

229. Sun W, Fu S. Role of cancer-associated fibroblasts in tumor structure, composition and the microenvironment in ovarian cancer. Oncol Lett 2019;18:2173-8. DOI PubMed PMC

230. Zhang B, Chen F, Xu Q, et al. Revisiting ovarian cancer microenvironment: a friend or a foe? Protein Cell 2018;9:674-92. DOI PubMed PMC

231. Sahoo SS, Zhang XD, Hondermarck H, Tanwar PS. The emerging role of the microenvironment in endometrial cancer. Cancers (Basel) 2018;10:408. DOI PubMed PMC

232. Murata T, Mekada E, Hoffman RM. Reconstitution of a metastatic-resistant tumor microenvironment with cancer-associated fibroblasts enables metastasis. Cell Cycle 2017;16:533-5. DOI PubMed PMC

233. Grivennikov SI, Greten FR, Karin M. Immunity, inflammation, and cancer. Cell 2010;140:883-99. DOI PubMed PMC

234. Janghorban M, Xin L, Rosen JM, Zhang XH. Notch signaling as a regulator of the tumor immune response: to target or not to target? Front Immunol 2018;9:1649. DOI PubMed PMC

235. Hossain F, Majumder S, Ucar DA, et al. Notch signaling in myeloid cells as a regulator of tumor immune responses. Front Immunol 2018;9:1288. DOI PubMed PMC

236. Kelliher MA, Roderick JE. NOTCH signaling in T-cell-mediated anti-tumor immunity and T-cell-based immunotherapies. Front Immunol 2018;9:1718. DOI PubMed PMC

237. Vijayaraghavan J, Osborne BA. Notch and T cell function - a complex tale. In: Borggrefe T, Giaimo BD, editors. Molecular mechanisms of Notch signaling. Cham: Springer International Publishing; 2018. p. 339-54. DOI

238. Cho OH, Shin HM, Miele L, et al. Notch regulates cytolytic effector function in CD8+ T cells. J Immunol 2009;182:3380-9. DOI PubMed PMC

239. Sugimoto K, Maekawa Y, Kitamura A, et al. Notch2 signaling is required for potent antitumor immunity in vivo. $J$ Immunol 
2010;184:4673-8. DOI PubMed

240. Saleem SJ, Conrad DH. Hematopoietic cytokine-induced transcriptional regulation and Notch signaling as modulators of MDSC expansion. Int Immunopharmacol 2011;11:808-15. DOI PubMed PMC

241. Palaga T, Wongchana W, Kueanjinda P. Notch signaling in macrophages in the context of cancer immunity. Front Immunol 2018;9:652. DOI PubMed PMC

242. Toor SM, Syed Khaja AS, El Salhat H, et al. Myeloid cells in circulation and tumor microenvironment of breast cancer patients. Cancer Immunol Immunother 2017;66:753-64. DOI PubMed PMC

243. Peng D, Tanikawa T, Li W, et al. Myeloid-derived suppressor cells endow stem-like qualities to breast cancer cells through IL6/STAT3 and NO/NOTCH cross-talk signaling. Cancer Res 2016;76:3156-65. DOI PubMed PMC

244. Song JH, Eum DY, Park SY, et al. Inhibitory effect of ginsenoside Rg3 on cancer stemness and mesenchymal transition in breast cancer via regulation of myeloid-derived suppressor cells. PLoS One 2020;15:e240533. DOI PubMed PMC

245. Liu H, Wang J, Zhang M, et al. Jagged1 promotes aromatase inhibitor resistance by modulating tumor-associated macrophage differentiation in breast cancer patients. Breast Cancer Res Treat 2017;166:95-107. DOI PubMed

246. Garrido MP, Torres I, Vega M, Romero C. Angiogenesis in gynecological cancers: role of neurotrophins. Front Oncol $2019 ; 9: 913$. DOI PubMed PMC

247. Yetkin-Arik B, Kastelein AW, Klaassen I, et al. Angiogenesis in gynecological cancers and the options for anti-angiogenesis therapy. Biochim Biophys Acta Rev Cancer 2021;1875:188446. DOI PubMed

248. Madu CO, Wang S, Madu CO, Lu Y. Angiogenesis in breast cancer progression, diagnosis, and treatment. J Cancer 2020;11:447494. DOI PubMed PMC

249. Beijnum JR, Nowak-Sliwinska P, Huijbers EJ, Thijssen VL, Griffioen AW. The great escape; the hallmarks of resistance to antiangiogenic therapy. Pharmacol Rev 2015;67:441-61. DOI PubMed

250. Haibe Y, Kreidieh M, El Hajj H, et al. Resistance mechanisms to anti-angiogenic therapies in cancer. Front Oncol 2020;10:221. DOI PubMed PMC

251. Gacche RN, Assaraf YG. Redundant angiogenic signaling and tumor drug resistance. Drug Resist Updat 2018;36:47-76. DOI PubMed

252. Benedito R, Hellström M. Notch as a hub for signaling in angiogenesis. Exp Cell Res 2013;319:1281-8. DOI PubMed

253. Liu Z, Fan F, Wang A, Zheng S, Lu Y. Dl14-Notch signaling in regulation of tumor angiogenesis. J Cancer Res Clin Oncol 2014;140:525-36. DOI PubMed

254. Akil A, Gutiérrez-García AK, Guenter R, et al. Notch signaling in vascular endothelial cells, angiogenesis, and tumor progression: an update and prospective. Front Cell Dev Biol 2021;9:642352. DOI PubMed PMC

255. Li JL, Sainson RC, Oon CE, et al. DLL4-Notch signaling mediates tumor resistance to anti-VEGF therapy in vivo. Cancer Res 2011;71:6073-83. DOI PubMed

256. Yang X, Shen F, Hu W, Coleman RL, Sood AK. New ways to successfully target tumor vasculature in ovarian cancer. Curr Opin Obstet Gynecol 2015;27:58-65. DOI PubMed PMC

257. Yeom DH, Lee YS, Ryu I, et al. ABL001, a bispecific antibody targeting VEGF and DLL4, with chemotherapy, synergistically inhibits tumor progression in xenograft models. Int J Mol Sci 2020;22:241. DOI PubMed PMC

258. Jubb AM, Harris AL. Biomarkers to predict the clinical efficacy of bevacizumab in cancer. Lancet Oncol 2010;11:1172-83. DOI PubMed

259. Li Y, Hickson JA, Ambrosi DJ, et al. ABT-165, a dual variable domain immunoglobulin (DVD-Ig) targeting DLL4 and VEGF, demonstrates superior efficacy and favorable safety profiles in preclinical models. Mol Cancer Ther 2018;17:1039-50. DOI PubMed

260. Zhou R, Wang S, Wen H, Wang M, Wu M. The bispecific antibody HB-32, blockade of both VEGF and DLL4 shows potent antiangiogenic activity in vitro and anti-tumor activity in breast cancer xenograft models. Exp Cell Res 2019;380:141-8. DOI PubMed

261. Hu W, Lu C, Dong HH, et al. Biological roles of the Delta family Notch ligand Dll4 in tumor and endothelial cells in ovarian cancer. Cancer Res 2011;71:6030-9. DOI PubMed PMC

262. Kuhnert F, Chen G, Coetzee S, et al. Dl14 blockade in stromal cells mediates antitumor effects in preclinical models of ovarian cancer. Cancer Res 2015;75:4086-96. DOI PubMed

263. Huang J, Hu W, Hu L, et al. D114 inhibition plus aflibercept markedly reduces ovarian tumor growth. Mol Cancer Ther 2016;15:1344-52. DOI PubMed PMC

264. Majidpoor J, Mortezaee K. Angiogenesis as a hallmark of solid tumors - clinical perspectives. Cell Oncol (Dordr) 2021;44:715-37. DOI PubMed

265. Li B, Tong $\mathrm{T}$, Ren N, et al. Theasaponin $\mathrm{E}_{1}$ inhibits platinum-resistant ovarian cancer cells through activating apoptosis and suppressing angiogenesis. Molecules 2021;26:1681. DOI PubMed PMC

266. Guan L. Endostar rebuilding vascular homeostasis and enhancing chemotherapy efficacy in cervical cancer treatment. Onco Targets Ther 2020;13:12811-27. DOI PubMed PMC

267. Coleman RL, Handley KF, Burger R, et al. Demcizumab combined with paclitaxel for platinum-resistant ovarian, primary peritoneal, and fallopian tube cancer: The SIERRA open-label phase Ib trial. Gynecol Oncol 2020;157:386-91. DOI PubMed

268. Jimeno A, Moore KN, Gordon M, et al. A first-in-human phase 1a study of the bispecific anti-DLL4/anti-VEGF antibody navicixizumab (OMP-305B83) in patients with previously treated solid tumors. Invest New Drugs 2019;37:461-72. DOI PubMed

269. IeM, Wang TL. Notch signaling, gamma-secretase inhibitors, and cancer therapy. Cancer Res 2007;67:1879-82. DOI PubMed

270. Majumder S, Crabtree JS, Golde TE, Minter LM, Osborne BA, Miele L. Targeting Notch in oncology: the path forward. Nat Rev Drug Discov 2021;20:125-44. DOI PubMed 
271. Panda M, Biswal BK. Cell signaling and cancer: a mechanistic insight into drug resistance. Mol Biol Rep 2019;46:5645-59. DOI PubMed

272. Valcourt DM, Dang MN, Wang J, Day ES. Nanoparticles for manipulation of the developmental Wnt, Hedgehog, and Notch signaling pathways in cancer. Ann Biomed Eng 2020;48:1864-84. DOI PubMed PMC 